Document downloaded from:

http://hdl.handle.net/10251/164534

This paper must be cited as:

Sohrabi, M.; Mohammadi, H.; León Santana, M.; Armengol Fortí, J.; Banihashemi, Z. (2020). Fungal pathogens associated with branch and trunk cankers of nut crops in Iran. European Journal of Plant Pathology. 157(2):327-351. https://doi.org/10.1007/s10658-020-01996-w

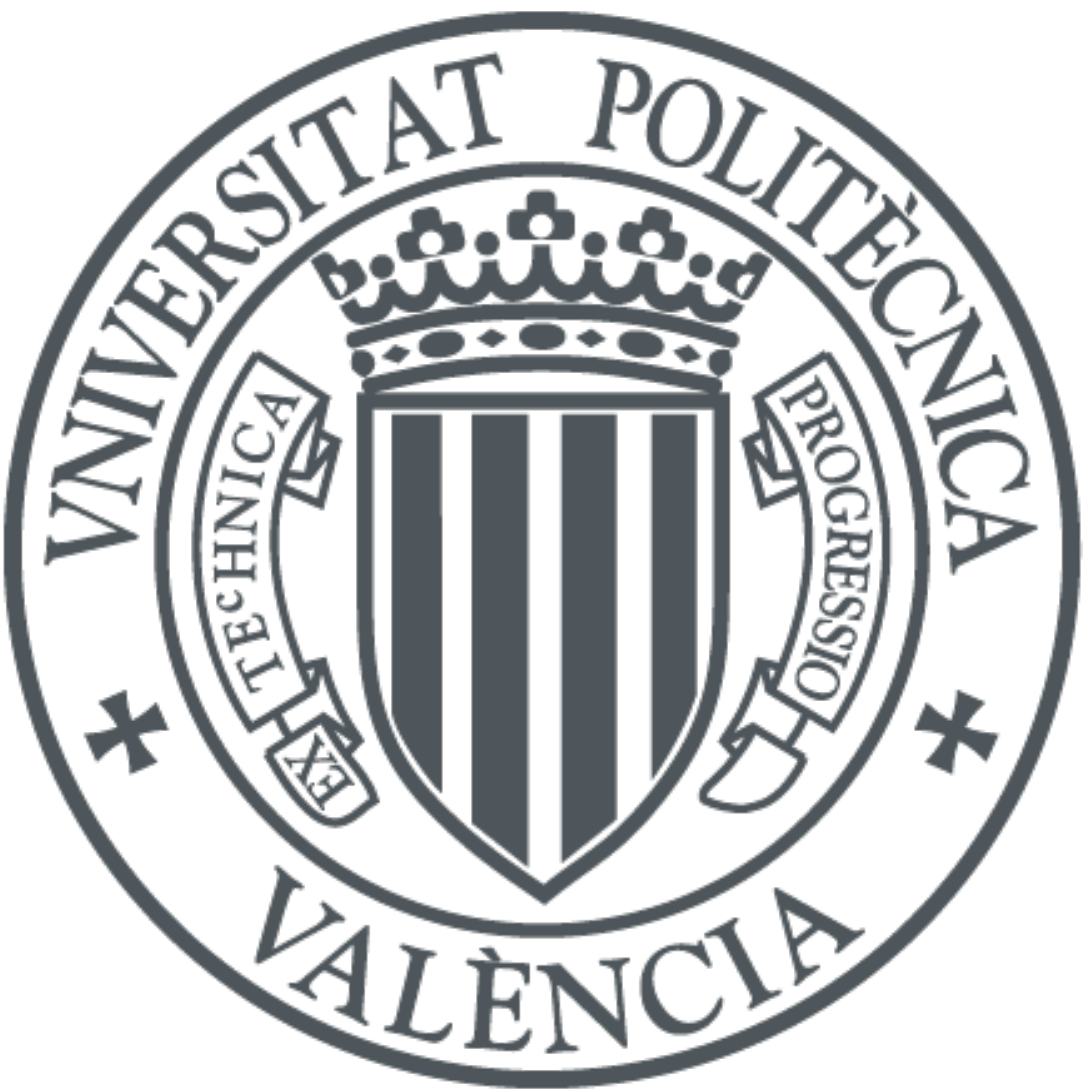

The final publication is available at

https://doi.org/10.1007/s10658-020-01996-w

Copyright Springer-Verlag

Additional Information 


\title{
Fungal pathogens associated with branch and trunk cankers of nut crops in
}

\author{
Iran
}

\section{Mahboobeh Sohrabi . Hamid Mohammadi . Maela León . Josep Armengol . Zia \\ Banihashemi}

Mahboobeh Sohrabi

Department of Plant Protection, Faculty of Agriculture, Shahid Bahonar University of Kerman, Kerman, Iran.

Hamid Mohammadi (hmohammadi@uk.ac.ir)

Department of Plant Protection, Faculty of Agriculture, Shahid Bahonar University of Kerman, Kerman, Iran.

Maela León

Instituto Agroforestal Mediterráneo, Universitat Politècnica de València, Camino de Vera S/N, 46022-Valencia (Spain).

\section{Josep Armengol}

Instituto Agroforestal Mediterráneo, Universitat Politècnica de València, Camino de Vera S/N, 46022-Valencia (Spain).

Zia Banihashemi

Department of Plant Protection, Faculty of Agriculture, Shiraz University, Shiraz, Iran.

\section{Acknowledgement}

Financial support by the Iranian Ministry of Science, Research and Technology (MSRT) for the first author during her 4 months stay in Spain as a part of her PhD project is greatly acknowledged. 


\section{Abstract}

Branch and trunk canker diseases have become prevalent on nut crops in Iran. During 2015 to 2018, extensive field surveys were conducted on 58 almond, 43 pistachio and 80 walnut orchards in Iran to study fungal pathogens associated with symptomatic trees. One hundred and fifty-six representative fungal isolates were selected and identified based on morphological characteristics and by phylogenetic comparison of DNA sequence data. Fungal species found were Collophorina hispanica, Pleurostoma richardsiae, nine species of Phaeoacremonium (namely P. angustius, $P$. cinereum, P. italicum, P. fraxinopennsylvanicum, P. minimum, P. parasiticum, P. scolyti, $P$. tuscanum and P. viticola), eleven species of Botryosphaeriaceae (namely Botryosphaeria dothidea, Diplodia gallae, D. mutila, D. seriata, Dothiorella plurivora, Do. sarmentorum, Do. viticola, Lasiodiplodia citricola, L. mahajangana, L. theobromae and Neofusicoccum parvum), four species of Diatrypaceae (namely Cryptosphaeria pullmanensis, Diatrype whitmanensis, Eutypella citricola and E. vitis) and two non-identified Eutypella spp. (Eutypella sp. 1 and Eutypella sp. 2). Some of these species represent new reports in Iran and/or are reported for the first time in their respective hosts. Pathogenicity tests demonstrated that most of these fungi were pathogenic to inoculated almond, pistachio and walnut shoots. Therefore, more importance should be given to fungal trunk pathogens in Iran, and specific management strategies should be included within the nut crops IPM management programs, with the aim of improving their sustainability.

Key words: Almond, Botryosphaeriaceae, Diatrypaceae, Phaeoacremonium, Pistachio,

\section{Walnut}




\section{Introduction}

Iran is one of the most important nut crops producing countries worlwide, with almonds, pistachios and walnuts of special agricultural importance to the country. Almond (Prunus dulcis, Rosaceae) is native to Mediterranean regions of the Middle East. Iran is considered the main center of origin of domestic almonds and one of the richest sources of germplasm diversity (Vezvaei 2003). Iran produces about 111,000 metric tons of almonds with 199,000 ha, being the fourth largest producer of this nut crop in the world (FAO 2018). Pistachio (Pistacia vera, Anacardiaceae), originates from Central Asia and the Middle East. Pistachio growing area in Iran is about 457,000 ha, producing 315,000 metric tons, being one of the world leading producers (FAO 2018). Walnut (Juglans regia, Juglandaceae) is one of the most traditional nut crops in Iran. This tree is known as the Persian walnut and Iran has been regarded as the region of origin of this species, where it was probably domesticated and then introduced to other regions of the world with temperate climate (McGranahan and Leslie 1991; Bayazit et al. 2007). According to FAO (2018), with 150,000 ha and 405,000 tons of walnut, Iran is the third largest producer of this crop in the world.

Nut crops are affected by many fungal pathogens, which can reduce their productivity dramatically (Teviotdale et al. 2002; Moral et al. 2019). Among them, branch and trunk canker diseases are becoming one of the most important limiting factors for nut crops production worldwide (Gramaje et al. 2016). Fungal species belonging to the genera Collophorina, Pleurostoma and Phaeoacremonium, and members of the Botryosphaeriaceae and Diatrypaceae families have been reported associated with branch and trunk canker diseases on almond, pistachio and walnut crops (Slippers et al. 2007; Trouillas et al. 2010a; Gramaje et al. 2012).

The genus Collophorina, was introduced by Damm et al. (2010) with five species, namely C. africana, C. capensis, C. paarla, C. pallida and C. rubra. These species were recovered from necrotic wood lesions of peach and nectarine trees in South Africa. Collophorina hispanica was reported causing wood cankers of almonds in Spain (Gramaje et al. 2012) and Iran (Arzanlou et al. 2016), and this fungus, together with C. paarla, was also isolated from branch cankers of almond in California (Holland et al. 2018).

Pleurostoma richardsiae (formerly Phialophora richardsiae) was previously reported as a human pathogen but, recently, the fungus has also been isolated from plants associated with esca and Petri disease of grapevine in California and Italy (Rolshausen et al. 2010; Carlucci et al. 2015a). A study conducted in Spain revealed that P. richardsiae was highly pathogenic to almond (Olmo et al. 2015).

Species of Phaeoacremonium are well known plant pathogens causing wilting and dieback of woody plants (Mostert et al. 2006; White et al. 2011; Gramaje et al. 2015). In Spain, P. amygdalinum and P. iranianum were isolated from almond trees showing internal necrosis and brown to black vascular streaking (Gramaje et al. 2012), and P. minimum was 
found associated with the decline of almond trees in nursery conditions (Marín-Terrazas et al. 2016). During a survey on stone fruit trees in Iran, P. minimum was also isolated from affected almond trees in Kerman province (Mousavi et al. 2014). In a study conducted by Mohammadi et al. (2015) in Iran, four species of Phaeoacremonium, P. cinereum, P. minimum, $P$. parasiticum and $P$. viticola were isolated from pistachio trees showing decline symptoms. In $2018, P$. sicilianum was reported from Juglans sp. in South Africa (Spies et al. 2018). Recently, this species has been isolated from walnut trees in The Czech Republic (Eichmeier et al. 2019). In Iran, a survey conducted by Mohammadi et al. (2013) in Ardabil province (northwest of Iran), identified of two species of this genus, $P$. cinereum and $P$. minimum from walnut trees showing dieback symptoms.

The family Botryosphaeriaceae contains many fungal species, which are considered saprophytes, endophytes or plants pathogens associated with a wide range of fruit, ornamental and forest trees (Phillips et al. 2013). On almond trees, band canker caused by Botryosphaeria dothidea was first reported in California in 1959 (English et al. 1966). In South Africa, Slippers et al. (2007) reported Neofusicoccum australe as a pathogen of almond trees. In USA, some species such as $B$. dothidea, Diplodia seriata, Dothiorella sarmentorum, Macrophomina phaseolina, N. mediterraneum, N. nonquaestium and $N$. parvum were reported from almond trees with different internal and external trunk canker disease symptoms (Inderbitzin et al. 2010). Subsequent surveys conducted on almond trees in California showed that Lasiodiplodia theobromae (Chen et al. 2013b), Do. iberica (Doll et al. 2015) and Neoscytalidium dimidiatum (Nouri et al. 2018) are also pathogens associated with branch cankers. In Spain, several Botryopshaeriaceae species such as $B$. dothidea, D. olivarum, D. seriata, N. luteum, N. mediterraneum and N. parvum have been reported from almond trees (Gramaje et al. 2012; Olmo et al. 2016). A panicle and shoot blight caused by B. dothidea was reported for the first time on pistachio in California in 1991. Shoot blight symptoms included dark brown to black lesions at the base of shoots (Michailides 1991). The fungus N. mediterraneum has also been described as a serious threat to the pistachio industry in California (Chen et al. 2014b; Michailides and Morgan 2004). This species had been also reported on pistachio in Spain (Moral et al. 2010), together with $N$. australe (Armengol et al. 2008). In 2014, eight Botryosphaeriaceae species were reported on pistachio trees in California; these included B. dothidea, D. seriata, Do. iberica, Do. sarmentorum, L. citricola, L. gilanensis, N. mediterraneum and $N$. vitifusiforme. In this work, B. dothidea and N. parvum were also reported from pistachio in Greece (Chen et al. 2014b). In another study, L. americana and N. hellenicum were reported from pistachio trees in USA and Greece, respectively (Chen et al. 2015). According to a study conducted by Mohammadi et al. (2015), B. dothidea, Do. viticola and N. parvum can infect pistachio trees in Iran. Several species of Botryosphaeriaceae including B. dothidea, D. mutila, D. seriata, Do. iberica, L. citricola, N. mediterraneum, N. nonquasitum N. parvum, N. vitifusiforme and Neoscytalidium dimidiatum have been isolated and reported from walnut trees in California (Inderbitzin et al. 2010; Trouillas et al. 2010b; Chen et al. 2013a, 2014a). N. parvum has also been reported from this host plant in China (Yu et al. 2015). Li et al. (2016) reported the occurrence of B. dothidea and L. pseudotheobromae on English walnut in China. 
In a recent survey conducted in The Czech Republic, D. seriata and Do. omnivora have been reported from English walnut (Eichmeier et al. 2019). Some members of the family Botryosphaeriaceae have also been reported from walnut trees in Iran. These include, B. dothidea, N. parvum (Abdollahzadeh et al. 2013), D. seriata (Mohammadi et al. 2013), and L. iraniensis (Abdollahzadeh et al. 2010).

Species of the family Diatrypaceae are predominantly saprotrophic on the decaying wood of trees. However, some species of this family are well known pathogens associated with declining plant hosts (Glawe and Rogers 1984). According to studies on trunk canker diseases conducted in different countries, various species in the family Diatrypaceae, including Eutypella, Eutypa and Cryptovalsa have been found associated with the decay of nut crops (Carter 1982; Gramaje et al. 2012; Rumbos 1984). Almond has been indicated as a host for Eutypella prunastri (Ellis and Ellis 1997). Eutypa lata is an important plant pathogen in the family Diatrypaceae having a worldwide distribution causing dieback and decline on many tree species worldwide. This species has been already reported on almond (Trouillas and Gubler 2010a; Gramaje et al. 2012; Moyo et al. 2018), pistachio (Rumbos 1986) and walnut trees (Rumbos 1984; Eichmeier et al. 2019). In California, Cryptovalsa ampelina has also been reported on walnut trees (Trouillas et al. 2010a). Eutypella sp. and Peroneutypa scoparia were isolated for the first time from walnut trees in 2019 (Eichmeier et al. 2019). In Iran, Cryptosphaeria pullmanensis has been reported from walnut trees (Raoufi et al. 2016).

Previous studies suggested that members of the familiy Botryosphaeriaceae and the genus Phaeoacremonium could constitute a threat to various plant species in Iran such as pistachio (Mohammadi et al. 2015), Prunus spp. (Abdollahzadeh et al. 2013; Soltaninejad et al. 2017) and pome fruit trees (Sami et al. 2014). However, there is scarce information about the incidence and identity of fungal trunk pathogens, specially Botryosphaeriaceae, Diatrypaceae, Collophorina, Phaeoacremonium and Pleurostoma species occurring on the main nut crops (almond, pistachio and walnut) cultivated in this country. Therefore, the main objectives of this study were: i) to gain more insight into the occurrence of these taxa on almond, pistachio and walnut trees showing branch cankers and trunk disease symptoms in Iran, and ii) to determine their pathogenicity on these hosts.

\section{Materials and Methods}

\section{Field surveys, fungal isolation and morphological characterization}

From 2015 to 2018, several field surveys were conducted in nut tree (almond, pistachio and walnut) orchards in Fars, Kerman, Kohgiloiyeh and Boirahmad, Isfahan and Yazd provinces in Iran to study fungal pathogens associated with branch and trunk canker diseases. Wood samples were collected from trunk and branches of trees showing cankers and dieback symptoms. Samples were also collected from pruning wood debris left in the orchards and inspected for the presence of fruiting bodies (pycnidia or ascocarps) on the bark surface. In this study 58 almond, 43 pistachio and 80 walnut orchards were visited. Wood samples were collected from 815 symptomatic trees including 294 almond, 181 
pistachio and 331 walnut trees. In total, 842 samples were obtained: almond (305 branches, 36.2\% total samples), pistachio (197 branches, 23.4\%) and walnut (340 branches, 40.4\%). One hundred and fifty wood pruning debris samples containing fruiting bodies were also collected, including 50 almond, 30 pistachio and 70 walnut wood fragments.

Fungal isolations were made by plating out small pieces of discolored wood tissue (4-5 mm) on potato dextrose agar (PDA, Merck, Germany) or malt extract agar (MEA, Merck, Germany) after surface sterilization. Wood chips were sterilised by placing them in $5 \%$ sodium hypochlorite for 2 min and then rinsed in sterile water for 3 min. Isolation of fungi from wood debris was carried out by direct transfer of fungal fruiting bodies (pycnidia) on MEA or preparation of suspension from spores in pycnidia and then transferring them on MEA. In all cases, plates were incubated at $25^{\circ} \mathrm{C}$ in darkness. Fungal colonies were transferred to PDA and later single-spored or hyphal-tipped in order to obtain pure cultures. All cultures were maintained in the culture collection of the Department of Plant Protection at the Shahid Bahonar Univesity of Kerman, Kerman. Obtained fungal isolates were tentatively identified based on the main morphological (colony and culture appearance) and microscopic characters (conidia, phialides and conidiophores).

Collophorina species were identified by the presence of conidiomata, microcyclic conidiation or endoconidia, additional to conidia formed on hyphae, as well as size and shape of conidia and conidiophores (Damm et al. 2010).

The Pleurostoma isolates were morphologically characterised on MEA (20gr malt extraction; 15 gr agar; Oxoid, UK), PDA (Biokar diagnostics, France), and oatmeal agar (OA; 60 g oatmeal; Fluca analytical, USA, 12.5 g agar; Oxoid, UK), incubated at $25 \pm 2{ }^{\circ} \mathrm{C}$ in the dark for $16 \mathrm{~d}$. Morphological identification of these isolates was based on the main characters such as conidiophore, phialides, collarettes and conidial morphology (Vijaykrishna et al. 2004; Carlucci et al. 2015a).

Species of Phaeoacremonium were identified based on colony and culture characters and microscopic structures. The isolates were grown on MEA, PDA and OA (Crous et al. 1996) and incubated at $25{ }^{\circ} \mathrm{C}$ in darkness. After 8 and 16 days, colony color and appearance, pigment production on the media and conidiophore morphology, phialide type and shape, size of hyphal warts and conidial size and shape were recorded for each isolate.

Botryosphaeriaceae spp. were induced to produce fruiting bodies by plating them on $2 \%$ water agar (Oxoid, UK) containing sterilised pine needles. Cultures were incubated at $23-25^{\circ} \mathrm{C}$ under near UV light with a $12 \mathrm{~h}$ photoperiod for 20-35 days (Phillips et al. 2013). Produced pycnidia were mounted in water and the length and width, shape, colour and septation of the conidia were evaluated and recorded for each isolate.

Colonies belonging to the Diatrypaceae family were identified based on their colony morphology on PDA and conidial size and shape (Glawe and Rogers 1984; Trouillas et al. 2010a, 2011).

\section{DNA extraction, PCR and DNA sequencing}

One hundred and fifty-six representative fungal isolates were selected for molecular identification: Almond ( $\mathrm{n}=51$ ), Pistachio $(\mathrm{n}=19)$ and Walnut $(\mathrm{n}=86)$ (Table S1). Prior to DNA extraction these isolates were grown on PDA for 10-20 
days and total genomic DNA was extracted from mycelium and conidia using CTAB method (Doyle and Doyle 1990). All DNA samples were incubated at $-17^{\circ} \mathrm{C}$ until use for PCR amplification. For Collophorina, Pleurostoma, Botryosphaeriaceae and Diatrypaceae isolates, the internal transcribed spacer 1 and 2 including the intervening 5.8S nrDNA gene (ITS) and for Botryosphaeriaceae and Collophorina, a portion of translation elongation factor 1-alpha (tef$1 \alpha=\mathrm{EF}$ ) region were amplified using primer sets ITS1/ITS4 (White et al. 1990) and EF1-728F/EF1-986R (Carbone and Kohn 1999) or EF1-688F/EF1-1251R (Alves et al. 2008), respectively. The amplification and sequencing of a portion of the glyceraldehyde-3-phosphate dehydrogenase (GDPH) of Collophorina were done using the primers GDF1 and GDR1 (Templeton et al. 1992). For Phaeoacremonium isolates, oligonucleotide primers T1 and Bt2b (Glass and Donaldson 1995) or BTCadF and BTCadR (Travadon et al. 2015) were used to amplify a part of $\beta$-tubulin gene (BT). Initial identification of these isolates was also confirmed by analysis of the actin (ACT) sequences amplified using ACT-512F and ACT-783R primers (Carbone and Kohn 1999). The polymerase chain reaction (PCR) was performed in an Applied Biosystems Veriti 96-well Thermal Cycler (Massachusetts, USA). Electrophoresis of the DNA samples and PCR products were performed on a $1.0 \%$ agarose gel (UltraPureTM Agarose, Invitrogen), stained with REALSAFE Nucleic Acid Staining Solution (Durvis S.L., Valencia, Spain). Bands were visualised under ultraviolet light and a 100-bp ladder (GeneRuler 100 bp DNA Ladder, Thermo Scientific, Vilnius, Lithuania) was used for evaluation of the band sizes. PCR products were purified and sequenced by Bioneer Corporation (Daejeon, South Korea) and Macrogen (Madrid, Spain). All sequences were read and edited with Sequencher software v. 1.8 (Gene Codes Corporation, Ann Arbor, MI), and then run through the BLAST (Basic Local Alignment Search Tool, http://blast.ncbi.nlm. nih.gov/Blast.cgi) to determine their basic identity.

\section{Phylogenetic analysis}

The sequences were grouped regarding the fungal families, genera or species and sequenced regions, forming different datasets. Five groups of sequence datasets were generated to confirm the identity of Collophorina hispanica, Pleurostoma richardsiae, Phaeoacremonium spp., Botryosphaeriaceae spp. and Diatrypaceae spp. isolates. For each group, individual loci sequences obtained in this study (Table S1) and those references retrieved from Genbank (Table S2, S3, S4 and S5) were aligned using default settings of ClustalW algorithm (Thompson et al. 1994) included within MEGAX software package (Kumar et al. 2018). The alignments were manually checked and improved where necessary. For multilocus analysis of C. hispanica, P. richardsiae, Phaeoacremonium spp., Botryosphaeriaeae spp. and Diatrypaceae spp., the single locus alignments were concatenated using SequenceMatrix 1.8 (Vaidya et al 2011). Phylogenetic analyses for each locus and concatenated datasets were based on Maximum Likelihood (ML) and Maximum Parsimony (MP). The ML analyses were done with the tool RAxML-HPC2 on XSEDE (Stamatakis, 2014) through the CIPRES Science Gateway 
V 3.3 (Miller et al. 2010). A nucleotide substitution model GTRGAMMA was used and the supports of the branches were calculated from 1000 bootstrap replicates. Maximum-parsimony analysis was performed in MEGA X (Kumar et al. 2018) with the Tree-Bisection-Reconnection (TBR) algorithm, where gaps were treated as missing data. Measures calculated for parsimony included tree length (TL), consistency index (CI), retention index (RI) and rescaled consistency index (RC). The robustness of the topology was evaluated by 1000 bootstrap replications (Felsenstein, 1985). Trees were visualized using MEGA X (Kumar et al. 2018) or Fig Tree 1.4.3 (http://tree.bio.ed.ac.uk/software/figtree/). All sequences were deposited in GenBank and were listed in Table S1. The alignments were deposited in TreeBASE under the study number S25374.

\section{Preliminary pathogenicity studies}

Fifty-six different fungal isolates representing the fungal species obtained from nut tree species in various locations were selected for pathogenicity studies (Tables 1, 2 and 3). Pathogenicity tests were conducted on detached shoots of almond (8-12 years old), pistachio (15-18 years old) and walnut (17-20 years old) trees under control conditions. Shoots were cut in a uniform length $(\sim 35 \mathrm{~cm}$ in length and $2.5 \mathrm{~cm}$ in diameter $)$ and the outer bark of them sprayed with $70 \%$ ethanol. After air drying, each shoot was wounded using a 4-mm sterilized cork borer and then a mycelial plug of the same size taken from the margin of fungal colonies on PDA (10-16 days old) was placed into the created wound. All inoculated sites were covered by moist cotton and then protected by wrapping with Parafilm (Pechiney Plastic Packaging, Menasha, USA). Six shoots per each fungal isolate were used and an equal number was also inoculated with 4 mm non-colonized potato dextrose agar plugs as control treatments. Treatment and control shoots were immediately placed into plastic containers, filled with distilled water $(2000 \mathrm{ml})$, covered with a transparent plastic bag and maintained at $25-27^{\circ} \mathrm{C}$. This experiment was arranged in a completely randomized design and repeated once. All inoculated shoots were collected after 40 days of incubation and the extent of wood discoloration in the wood was measured upward and downward from the point of inoculation. Data were checked by means of Shapiro-Wilk and Kolmogorov-Smirnov tests. Data from the pathogenicity assay was subjected to analysis of variance (one-way ANOVA) using SAS v 9.1 (SAS Institute, Cary, North Carolina, USA). LSD (The least significant difference) test was used for comparison of all treatment means at $P$ $<0.05$. Fifteen small segments of discolored wood tissues were cut from the edges of lesions produced on the test and control shoots and placed on PDA. Re-isolated fungi were identified as described previously, fulfilling Koch's postulates.

\section{Results}

\section{Sampling and collection of fungal isolates}


The most important external disease symptoms observed on almond, pistachio and walnut trees were yellowing, gumming, branch cankers and dieback. Internal symptoms included central, irregular, watery or v-shaped necrosis, brown to black wood streaking, and black spots, which were observed in cross sections of diseased branches (Fig. 1).

Fruiting bodies of Botryosphaeriaceae and Diatrypaceae isolates were detected on the surface of the wood debris collected in almond, pistachio and walnut orchards.

In total, 156 representative fungal isolates were selected from symptomatic tissues and wood debris of almond, pistachio and walnut trees. Of these, 133 isolates were obtained from internal wood lesions and 23 isolates were obtained from wood debris. Based on their appearance in culture, morphological and microscopic characteristics, isolates were divided into five main groups including Collophorina (5 isolates), Pleurostoma (10 isolates), Phaeoacremonium, (52 isolates), Botryosphaeriaceae (46 isolates: 25 from infected wood tissues and 21 isolates from wood debris), Diatrypaceae (43 isolates; 41 isolates from discolored wood tissues and 2 isolates from wood debris) (Table S6).

Collophorina isolates formed white to reddish cream colonies on PDA. Members of this group had slow growing mycelium, turning red to blood colour with age and produced a red pigment that coloured the colony and surrounding medium. According to these morphological features, all isolates were tentatively identified as Collophorina hispanica (Gramaje et al. 2012).

Pleurostoma isolates were characterized by Phialophora-like asexual morph and brown to olive-brown colonies on MEA. This group produced two different types of conidia, brown globose conidia, and hyaline, allantoid to cylindrical conidia. Morphological characteristics recorded for these isolates were consistent with the description of $P$. richardsiae (Vijaykrishma et al. 2004).

Phaeoacremonium isolates were characterized by pale to pale brown to reddish brown flat slow-growing cultures on MEA. Isolates of this group had three types of phialides that were different in size and shape. Sporulation was abundant and conidia were hyaline and aseptate. These characters were consistent with the description of genus Phaeoacremonium (Crous et al. 1996; Mostert et al. 2006).

Botryosphaeriaceae isolates were characterized by dark green or grey to dark grey fast-growing mycelium on PDA. These isolates produced black and globose fruiting bodies (pycnidia) on pine needles after 16 to 25 days. Conidia were hyaline or pigmented (Phillips et al. 2013; Slippers et al. 2013; Dissanayake et al. 2016). Based on conidial characteristics these isolates were divided to four subgroups. Some isolates formed conidia narrowly fusiform or irregularly fusiform and were tentatively identified as Neofusicoccum spp. or Botryosphaeria spp. In other isolates the conidia were initially hyaline, aseptate, thick-walled, becoming 1-2-septate and pale transluscent brown after discharge from the pycnidia. These characteristics were consistent with the description of Diplodia spp. Conidia in some isolates were initially hyaline, becoming dark brown and one-septate within the pycnidia. These isolates were tentatively identified as Dothiorella spp. 
Finally, some isolates of this group produced sub-ovoid to ellipsoid ovoid, initially hyaline and aseptate, dark brown 1septate conidia after discharge from the conidiomata, showing longitudinal striations. All these isolates were tentatively identified as Lasiodiplodia spp. (Phillips et al. 2013; Slippers et al. 2013).

Diatrypaceae isolates were characterized by having white to white-cream cottony slow-growing mycelium on PDA which gradually darkened in the center. Isolates of this group formed small pycnidia on pine needles under continuous fluorescent light after 3-4 weeks. Conidia were filiform and mostly curved in shape, which these morphological features correspond to descriptions of species in the Diatrypaceae family (Glawe and Rogers 1984).

\section{Molecular characterization and phylogenetic analyses}

Molecular characterization allowed to confirm the identity of the 156 isolates included in this study. Regarding Collophorina and Pleurostoma isolates, all of them belonged to the same species: C. hispanica and P. richardsiae, respectively. The tree topologies of the phylogenies were overall highly concordant between ML and MP inferences. The MP trees are presented, with ML and MP support values at branches for Phaeoacremonium, Botryosphaeriaceae and Diatrypaceae.

For Collophorina analysis, the ITS region was sequenced from all isolates, and fragments of EF and GAPDH were sequenced from some of them. The concatenated alignment consisted of 21 isolates ( 5 Iranian isolates, 15 references and 1 outgroup) and 925 characters including gaps (EF: 302, ITS: 480 and GAPDH: 143). The MP analysis resulted in 8 equally most parsimonious trees $(\mathrm{TL}=527, \mathrm{CI}=0.872, \mathrm{RI}=0.918, \mathrm{RC}=0.8)$. All Iranian isolates were grouped in the same clade with the $C$. hispanica ex-type, with $100 \%$ of bootstrap (Fig. 2).

For Pleurostoma analysis, the ITS region was sequenced in all isolates but one (IRNKPH210) (n=9), while BT sequence was generated from representative isolates $(n=5)$. The ACT sequence was generated only from IRNKPH210. The two individual phylogenetic analysis (ITS and BT) resulted in similar tree topology (data not shown). The combined alignment of the Iranian isolates with both sequences $(\mathrm{n}=5)$, four sequences of reference isolates and $P$. fraxinopensilvanicum CBS101585 as outgroup, consisted of 1237 characters including gaps (ITS: 514 and BT: 723 ). The MP analysis resulted in 5 equally most parsimonious trees $(\mathrm{TL}=737, \mathrm{CI}=0.823, \mathrm{RI}=0.806, \mathrm{RC}=0.663)$. The Iranian isolates clustered with the reference isolate of P. richardsiae (100\% bootstrap support) (Fig. 3).

For the Phaeoacremonium analysis, the BT sequences were obtained from all Phaeoacremonium suspected isolates $(n=51)$, while ACT sequences were obtained from a selection of them $(n=33)$ (Table S1). The concatenated alignment included the isolates with both sequences and consisted of 73 taxa (33 representative Iranian isolates, 39 references and 1 outgroup) with 827 characters (ACT: 226 and BT: 601) including gaps. In the concatenated alignment, 316 characters were conserved and 384 were parsimony informative. The heuristic search resulted in 10 equally most parsimonious trees with $\mathrm{TL}=1211, \mathrm{CI}=0.611, \mathrm{RI}=0.916$ and $\mathrm{RC}=0.56$. The $\mathrm{MP}$ tree showed that Iranian isolates belonged to 9 of 23 clades 
of described Phaeoacemonium species (Fig. 4). The ITS region of the Iranian P. cinereum isolates was also sequenced because in the sequences of the ACT and BT regions, 8 and 6 nucleotide differences were found respectively. The sequence of the ITS region presented 1 difference. These sequence differences did not result into morphological changes that supported the separation of these isolates as a new species. The most frequently species were $P$. italicum (n=18), $P$. minimum $(\mathrm{n}=12)$ and $P$. parasiticum $(\mathrm{n}=8)$. One or two isolates were identified from the species $P$. angustius $(\mathrm{n}=2), P$. scolyti $(\mathrm{n}=1)$, P. tuscanum $(\mathrm{n}=1)$ and P. fraxinopensilvanicum $(\mathrm{n}=1)$.

For the Botryosphaeriaceae analysis, the ITS and EF sequences were generated for 46 isolates and aligned with 50 reference sequences and three outgroups. The combined alignment consisted of 942 characters including gaps (ITS: 588 and EF: 354). Of these, 596 were constant and 333 parsimony informative. Maximum parsimony analysis resulted in 3 equally most parsimonious trees $(\mathrm{TL}=715, \mathrm{CI}=0.729$; $\mathrm{RI}=0.963, \mathrm{RC}=0.702)$. The showed $\mathrm{MP}$ tree revealed 36 wellsupported clades corresponding to established species (Fig. 5). Our isolates belonged to 12 of them, being Diplodia the dominant genus (37\%), followed by Botryosphaeria (26\%) and Lasiodiplodia (20\%), being Botryosphaeria dothidea $(\mathrm{n}=12)$, D. seriata $(\mathrm{n}=10)$ and L. theobromae $(\mathrm{n}=7)$ were the principal species isolated. Diplodia mutila $(\mathrm{n}=4)$, D. gallae $(\mathrm{n}=3)$, L. citricola $(\mathrm{n}=1)$, L. mahajangana $(\mathrm{n}=1)$, N. parvum, Do. sarmentorum $(\mathrm{n}=2)$, Do. viticola $(\mathrm{n}=2)$, and Do. plurivora $(\mathrm{n}=2)$ were the other species identified.

For the Diatrypaceae analysis, the ITS sequences of 43 suspected Diatrypaceous isolates were aligned with 27 sequences of reference isolates and two of Cryptovalsa ampelina (CBS117485 and DMO100) were used as outgroup. The alignment consisted of 538 characters (including gaps), of which 350 were constant and 177 parsimony informative. Maximum parsimony analysis resulted in 7 equally most parsimonious trees $(\mathrm{TL}=382, \mathrm{CI}=0.661 ; \mathrm{RI}=0.924, \mathrm{RC}=0.611)$. Analysis of the ITS region clearly separated Iranian isolates in 6 clades, 4 of them belonged to the previous described species Eutypella vitis $(\mathrm{n}=4)$, E. citricola $(\mathrm{n}=2)$, Diatrype whitmanensis $(\mathrm{n}=1)$ and Cryptosphaeria pullmanensis $(\mathrm{n}=10)$. The remaining isolates $(\mathrm{n}=26)$ formed 2 well supported clades named here as Eutypella $\mathrm{sp} .1(\mathrm{n}=23)$ and Eutypella $\mathrm{sp} .2$ (n=3). Eutypella sp. 1 was closely related to E. cerviculata, E. semicircularis and Anthostoma decipiens with 90.8, 90.6 and 91.3 percentage of identities respectively. Eutypella sp. 2 was closely related to E. citricola and E. vitis with 95.7 and 94.7 percentage of identities respectively (Fig. 6).

\section{Pathogenicity tests}

Mean lengths of the extent of wood discolorations caused by inoculated isolates on almond, pistachio and walnut branches are shown in Tables 1, 2 and 3, respectively. Based on our results, all inoculated isolates produced brown to dark wood discoloration upward and downward from the point of inoculation after 40 days of incubation (some isolates shown in Fig. 7). 
On almond shoots, the longest lesions were caused by isolate IRNBS8 (D. gallae), although there was no significant difference between length of lesions produced by this isolate and the isolates: IRNBS54 (L. theobromae) and IRNBS30 (N. parvum). Isolates IRNM32-2 (Eutypella sp. 1) and IRNEU1 (D. whitmanensis) resulted in the smallest lesions on this host and were not significantly different from those of the control treatments. Re-isolation percentages of fungi inoculated on almond shoots ranged between 43\% (D. seriata, isolate IRNBS15) and 86\% (P. minimum, isolate IRNKPH178).

On pistachio shoots all fungal isolates produced wood lesions statistically different to those caused by the controls. Eutypella sp. 2 (isolate IRNM1, $108.4 \mathrm{~mm}$ ) and one isolate of $B$. dothidea (isolate IRNBS61, $96.0 \mathrm{~mm}$ ) were the most aggressive isolates, while E. citricola (IRNM4) gave the shortest lesions (34.4 mm) on detached shoots of this host. Reisolation of the inoculated isolates ranged from $43 \%$ (D. seriata, isolate IRNBS71 and E. citricola, IRNM4) to $78 \%$ (Eutypella sp. 2, isolate IRNM1).

On detached shoots of walnut, the isolate IRNKB245 (L. theobromae) was the most aggressive, causing the longest $(244.4 \mathrm{~mm})$ wood lesions $(P<0.05)$, although there were no significant differences among the length of wood lesions produced by this isolate and IRNBS6 (D. gallae), IRNBS19 (B. dothidea) and IRNM8 (Eutypella sp. 2). Isolates IRNKPH176 and IRNKPH209 (P. italicum), IRNKB211 (D. seriata), IRNKB213 (B. dothidea), IRNKB220 (Do. plurivora) and IRNKPH177 (P. cinereum) were the less aggressive; they produced lesions not significantly different from the controls $(11.4 \mathrm{~mm})$. The highest recovery percentage was recorded for L. theobromae (93\%) and the lowest for Do. viticola, Eutypella sp. 1, Eutypella sp. 2, P. cinereum (IRNK72S) (50\%). None of the fungal species were re-isolated from the small lesions observed on the control shoots in any of the hosts species inoculated.

\section{Discussion}

In recent years, extensive studies have been carried out throughout the world about branch and trunk canker diseases caused by fungal pathogens on various woody plants, including nut trees. However, relatively few of these researches have focused on nut trees in Iran, which is an important world producer of almond, pistachio and walnut. Therefore, this is the most extensive and comprehensive study on these diseases in this country, where the surveys were conducted in five provinces.

The most frequent external disease symptoms were branch cankers and dieback, and cross sections from wood samples revealed a diverse range of internal wood necrosis. Similar internal wood lesion types had been previously described by various authors on different woody plants, such as grapevine (Mostert et al. 2006; White et al. 2011), date palm (Mohammadi 2014), pome fruit trees (Cloete et al. 2011; Sami et al. 2014), pistachio (Mohammadi et al. 2015; Nouri et al. 2019) and some forest and ornamental trees (Hashemi et al. 2017; Kazemzadeh Chakusary et al. 2017). Moreover, wood debris samples examination revealed the presence of Botryosphaeriaceae and Diatrypaceae fruiting bodies. 
Based on morphological characters and DNA sequence data, a high diversity of fungal species was found on almond, pistachio and walnut samples. These include $C$. hispanica, $P$. richardsiae, nine Phaeoacremonium species $(P$. angustius, P. cinereum, P. italicum, P. fraxinopennsylvanicum, P. minimum, P. parasiticum, $P$. scolyti, $P$. tuscanum and $P$. viticola $)$, eleven Botryosphaeriaceae species B. dothidea, D. gallae, D. mutila, D. seriata, Do. plurivora, Do. sarmentorum, Do. viticola, L. citricola, L. mahajangana, L. theobromae and N. parvum, and four species of Diatrypaceae (C. pullmanensis, D. whitmanensis, E. citricola and E. vitis) and two non-identified Eutypella spp. (Eutypella sp. 1 and Eutypella sp. 2). In some cases, more than one species or taxon was retrieved from the same plant sample, as previously found by other authors (Gramaje et al. 2012; Sami et al. 2014; Mohammadi et al. 2015; Kazemzadeh Chakusary et al. 2017; Panahandeh et al. 2019).

Collophorina hispanica was isolated only from almond trees. This species was obtained from different internal wood necrosis. Gramaje et al. (2012) characterized C. hispanica, as new species from diseased almond trees showing black spots and dark brown to black streaking of the xylem tissues in Spain. This species was reported associated with branch cankers of almond in California (Holland et al. 2018). A survey about fungal trunk pathogens of almond trees conducted in north-west of Iran showed that $C$. hispanica is a dominant species associated with diseased almond trees in this country (Baradaran Bagheri et al. 2015; Arzanlou et al. 2016).

In our work, $P$. richardsiae was isolated from irregular wood necrosis in walnut trees and different internal symptoms in almond samples. Our results are consistent with previous studies in which this species was also recognized as trunk pathogen. Canale et al. (2019) isolated this fungus from olive trees with dark streaking in the inner wood tissues and necrosis symptoms. This pathogen has also been reported from grapevine in South Africa, California, Italy and Spain (Halleen et al. 2007; Rolshausen et al. 2010; Carlucci et al. 2015a; Varela et al. 2016), olive in Italy (Carlucci et al. 2013) and almond in Spain (Olmo et al. 2015). This is the first report of $P$. richardsiae associated with diseased walnut trees in the world.

Phaeoacremonium spp. were one of the most abundant fungal groups isolated from different internal wood necrosis. Nine Phaeoacremonium species were isolated from almond, pistachio and walnut trees in this study. These included, $P$. angustius, P. cinereum, P. italicum, P. fraxinopennsylvanicum, P. minimum, P. parasiticum, P. scolyti, P. tuscanum and P. viticola. Of these, only $P$. minimum, $P$. parasiticum and $P$. viticola were obtained from all the three hosts. Phaeoacremonium angustius has been reported from grapevine in Portugal (Chicau et al. 2000), Spain (Garcia-Benavides et al. 2013), apple and grapevine in USA (Groenewald et al. 2001; Rooney-Latham et al. 2005) and quince trees in Germany (Gierl and Fischer 2017). This study is the first report of $P$. angustius from Iran and also the first report of this fungus from almond trees in the world. Phaeoacremonium cinereum was isolated only from walnut trees. This species has been previously reported from diseased grapevines in Iran and Spain (Gramaje et al. 2009) and necrotic wood of 
walnut trees in Iran (Mohammadi et al. 2013). Phaeoacremonium fraxinopennsylvanicum has been identified from different woody hosts such as, black alder in Iran (Kazemzadeh Chakusary et al. 2017), apple in Iran (Sami et al. 2014) and South Africa (Spies et al. 2018) and grapevine in South Africa (White et al. 2011) and Iran (Mohammadi 2011). Our study is the first report of $P$. fraxinopennsylvanicum on walnut trees in the world. Phaeoacremonium italicum was the most abundant species in walnut trees. This taxon was also found on almond trees in our surveys. This species was previously detected from quince, common fig, apple, Chinaberry, Morus sp., olive, peach, common guava, pomegranate and grapevine (Spice et al. 2018). Our study shows for the first time that almond and walnut wood tissues can be colonized by P. italicum. Phaeoacremonium minimum was isolated from almond, pistachio and walnut trees. This fungus was the dominant Phaeoacremonium species on almond trees. This species has been previously reported from different host plants such as almond (Mousavi et al. 2014; Marín-Terrazas et al. 2016; Spies et al. 2018), pistachio (Mohammadi et al. 2015), walnut (Mohammadi et al. 2013), ornamental and forest trees (Kazemzadeh Chakusari et al. 2017), apple (Cloete et al. 2011; Arzanlou et al. 2014; Sami et al. 2014) and olive (Úrbez-Torres et al. 2013; Spies et al. 2018). Phaeoacremonium parasiticum was the most common species on pistachio trees. This species was also the prevalent species in a previous study about trunk pathogens of pistachio trees in Iran conducted by Mohammadi et al. (2015). This fungus has been retrieved from a wide range of plant hosts (Mostert et al. 2006; Gramaje et al. 2015; Spies et al. 2018). It was previously recorded on cypress (Mohammadi et al. 2014), pome and stone fruit (Sami et al. 2014; Soltaninejad et al. 2017), date palm (Mohammadi 2014) and some forest trees such as Caucasian zelkova, Persian iron wood, Persian poplar, European hornbeam and smooth leaf elm (Kazemzadeh Chakusari et al. 2017) and more recently from Java plum (Panahandeh et al. 2019) in Iran. In this study, only one isolate of P. scolyti was obtained from walnut trees. This fungus has previously been reported from persimmon, apple, almond and loquat (Spies et al. 2018), olive (Carlucci et al. 2013; Spies et al. 2018), stone fruit trees (Damm et al. 2008) and grapevine (Gramaje et al. 2008). In Iran, this species has also been isolated from quince and pear (Sami et al. 2014), Persian iron wood and pomegranate (Kazemzadeh Chakusari et al. 2017). Based on literature reviews, this is the first report of $P$. scolyti associated with necrotic wood of walnut trees in the world. Phaeoacremonium tuscanum was only found on walnut trees. This species has been reported from grapevine in Italy (Essakhi et al. 2008) and grapevine and peach in Iran (Mohammadi 2012; Soltaninejad et al. 2017). This study also represents the first record of $P$. tuscanum on walnut trees. In our survey, $P$. viticola was isolated from all three nut crops studied. This species was reported affecting grapevine (Mostert et al. 2006; Dupont et al. 2000), kiwifruit in France (Hennion et al. 2001), quince, loquat, common guava, oak, willow and plum trees in South Africa (Damm et al. 2008, Spies et al. 2018) and mountain-ash in Germany (Mostert et al. 2006). In Iran P. viticola has been reported from pistachio (Mohammadi et al. 2015) and cherry (Soltaninejad et al. 2017). Therefore, the current study is the first report of $P$. viticola associated with branch canker and dieback on almond and walnut trees worldwide. 
Eleven species of Botryosphaeriaceae were recovered from walnut, pistachio and almond trees. These include $B$. dothidea, D. gallae, D. mutila, D. seriata, Do. plurivora, Do. sarmentorum, Do. viticola, L. citricola, L. mahajangana, L. theobromae and N. parvum. Of these B. dothidea and D. seriata were only isolated from all three hosts. Six species, including B. dothidea, D. gallae, D. seriata, Do. plurivora, L. theobromae and N. parvum were collected from both affected trees and wood debris, while Do. sarmentorum was only obtained from wood debris. Most of them were recovered from walnut (10 species) followed by almond (6 species) and pistachio ( 2 species). Of the Botryosphaeriaceae species detected in this study, B. dothidea, D. seriata and L. theobromae were the most frequent species. B. dothidea, D. seriata and $N$. parvum are considered as the most common species associated with grapevine decline in Spain (Armengol et al. 2001, Aroca et al. 2006). D. seriata was one of the most frequently isolated Botryosphaeriaceae species in almond in Spain (Olmo et al. 2016), apricot, nectarine, peach and Japanese plum in South Africa (Damm et al. 2007), apple, pear and peach in Uruguay (Sessa et al. 2016) and stone fruit trees in South Africa (Slippers et al. 2007). In Iran, B. dothidea has been already reported as the most common Botryosphaeriaceae species in pistachio, and D. seriata, N. parvum and B. dothidea were reported from stone fruit trees (Mohammadi et al. 2015; Soltaninejad et al. 2017). Botryosphaeria dothidea was isolated from almond, pistachio and walnut trees. This species causes canker diseases in hundreds of plant species worldwide, including almond and several Prunus spp. (English et al. 1966; Inderbitzin et al. 2010; Gramaje et al. 2012), pistachio (Michailides 1991; Chen et al. 2014b), walnut (Li et al. 2016) and grapevine (Van Niekerk et al. 2006; Úrbez-Torres and Gubler 2009). In Iran, this fungus was previously found associated with apricot and sour cherry trees (Soltaninejad et al. 2017), almond (Ershad 2009), pistachio (Mohammadi et al. 2015) and walnut (Abdollahzadeh et al. 2013). Three species of Diplodia, D. seriata, D. gallae and D. mutila were found in this study. D. seriata has been reported from more than 250 plant hosts in the world. This species has been isolated from almond, pistachio and walnut trees (Inderbitzin et al. 2010; Gramaje et al. 2012; Chen et al. 2014a, b). In Iran, this fungus has previously been reported from walnut and pistachio trees (Mohammadi et al. 2013, 2015). Based on literature reviews, this is the first report of $D$. seriata associated with necrotic wood of almond trees in Iran. Three isolates of D. gallae were obtained in this study. Of these, two isolates were collected from wood pruning debris of almond trees and one isolate was also obtained from affected branches of walnut. This species was first described as Sphaeria gallae by D. von Schweinitz to name a fungus associated with galls on Quercus in the USA. The fungus was subsequently placed in several different genera, namely Aplosporella, Botryodiplodia, Macroplodia, and Sphaeropsis. These results suggested that this fungus has dark conidia, which correlate with the strains clustering in Diplodia (Yang et al. 2017). This species has been reported as a causal agent of canker of oak trees (Croghan and Robbin 1986). Therefore, almond and walnut trees are reported here as two new woody plant hosts for this fungus. In our survey D. mutila was isolated only from almond trees. This pathogen has been reported associated with various forest and fruit trees such as lawson cypress, Fraxinus sp., Populus sp., English yew (Phillips et al. 2013), walnut trees (Chen et al. 2014a), grapevine (Carlucci et al. 2015b), apple (Úrbez-Torres et al. 2016), date palm 
(Mohammadi, 2014) and peach, cherry, apricot (Soltaninejad et al. 2017). However, this is the first report of $D$. mutila on almond trees worldwide. In our survey, three species of Lasiodiplodia, namely L. theobromae, L. citricola and $L$. mahajangana were isolated from almond and walnut trees. Of these, L. theobromae was obtained from infected wood tissues of almond and walnut trees as well as wood debris of almond trees. This species has a wide host range and is widely distributed in tropical and subtropical regions (Dissanayake et al. 2016). It has previously been reported as the cause of canker and dieback in many woody plants such as walnut (Haggag et al. 2007), almond, pistachio (Chen et al. 2013b, 2014b), olive (Úrbez-Torres et al. 2013), mango (Abdollahzadeh et al. 2010) and stone fruit trees (Soltaninejad et al. 2017). Our work represents the first report of this species on almond and walnut trees in Iran. Only one isolate of $L$. citricola was obtained from walnut trees. This species was originally described from Citrus sp. in Iran (Abdollahzadeh et al. 2010). It has also been documented on peach, pistachio (Chen et al. 2013c, 2014b) and grapevine (Carlucci et al. 2015b). According to Chen et al. (2013a, 2014a), L. citricola could cause death of newly grafted walnut trees and infecting walnut trees. Although L. citricola has been reported to occur on walnut in other countries, the fungus was found for the first time associated with this nut tree in Iran. Lasiodiplodia mahajangana was recovered from walnut trees. This species was first described from Indian almond in Madagascar (Begoude et al. 2011). However, since then this species has been also detected from candelabra and Australian baobab trees in South Africa and Australia, respectively (Van der Linde et al. 2011). More recently, Kazemzadeh Chakusari et al. (2019) isolated and reported this taxon from Caucasian walnut, chestnut-leaved oak, Caucasian zelkova and Smooth leaf elm in the north of Iran. Therefore, walnut tree is reported here as new woody host for this pathogen. In the present study, we isolated three species of Dothiorella, namely Do. plurivora, Do. sarmentorum and Do. viticola, from branch samples and wood debris of walnut trees. Dothiorella plurivora was recovered from walnut, apple, apricot and grapevine in Spain and Citrus sp., Australian pine tree, apple, apricot, Eucalyptus sp. and Mediterranean cypress in Southern Iran (Abdollahzadeh et al. 2014). This species has also been isolated from peach and Japanese plum in South Africa (Damm et al. 2008). During a field survey conducted throughout forest areas in the north of Iran, this taxon was also reported from Caucasian persimmon, chestnut-leaved oak, black alder and Persian poplar (Kazemzadeh Chakusary et al. 2019). To our knowledge, this is the first report of Do. plurivora from branches and wood debris of walnut trees in Iran. In our work, Do. sarmentorum was only detected on the wood debris of walnut trees. Do. sarmentorum is a plurivorous species and has been isolated from 34 different host species (Phillips et al. 2013). In Iran, this fungus has been reported from fruit and forest trees such as field elm (Hashemi et al. 2017), quince and also from adult beetles of Osphranteria coerulescens (Mohammadi and Sharifi 2016), oak and black alder (Kazemzadeh Chakusari et al. 2019) and walnut (Ershad 2009). Results of this study showed that Do. sarmentorum can survive and sporulate on wood debris of walnut. In the current work only one isolate of Do. viticola was detected from walnut trees showing branch dieback. This fungus has been isolated from different hosts, such as grapevine (Urbez-Torres et al. 2007; Slippers et al. 2013), Citrus sp. (Abdollahzadeh et al. 2014; Hamrouni et al. 2018), Prunus sp. (Damm et al. 
2007; Soltaninejad et al. 2017), and pistachio (Mohammadi et al. 2015). This species has not been detected from walnut trees previously, therefore this is the first record of Do. viticola on walnut in the world. Neofusicoccum parvum was obtained from diseased walnut trees and wood debris of almond. This cosmopolitan species occurs on many woody plants worldwide. Our findings from wood debris of almond trees allowed the obtention of three isolates of N. parvum. This species has been reported in several countries and has also been isolated from various woody plants such as walnut (Inderbitzin et al. 2010; Chen et al. 2014a; Abdollahzadeh et al. 2013), stone fruit trees (Slippers et al. 2007; Inderbitzin et al. 2010; Soltaninejad et al. 2017), Mediterranean cypress (Mohammadi et al. 2014) and pistachio (Chen et al. 2014b; Mohammadi et al. 2015).

In the current study, four species of Diatrypaceae were detected from nut trees, including C. pullmanensis, D. whitmanensis, E. citricola and E. vitis. Additionally, two taxa could not be identified to the species level but were closely related to Eutypella (Eutypella sp. 1 and Eutypella sp. 2). Several species in the genera of Cryptosphaeria, Eutypa, Cryptovalsa, Diatrype and Diatrypella are known to occur on grapevines worldwide (Mostert et al. 2004; Trouillas and Gubler 2004; Pitt et al. 2009; Trouillas et al. 2010a, 2011). Cryptosphaeria pullmanensis was only recovered from walnut. This species was first described by Glawe (1984) from fallen branches of western balsam-poplar and then was detected from some woody plants such as grapevine in California (Trouillas et al. 2010a), fremont's cottonwood in USA (Trouillas et al. 2015; Trouillas and Gubler 2016), white willow and white poplar in China (Ma et al. 2016), and walnut in Iran (Raoufi et al. 2016). Only one isolate of $D$. whitmanensis was obtained from almond trees in this study. This species has been reported from big leaf maple, grapevine and California buckeye trees in California (Trouillas et al. 2010a) and elm trees in Iran (Hashemi et al. 2017). This study represents the first record of D. whitmanensis on almond in the world. We found two species of Eutypella, namely E. citricola and E. vitis from pistachio and walnut trees, respectively. Eutypella citricola has been isolated from Citrus spp. in Southern California (Mayorquin et al. 2016), grapefruit, orange, grapevine in Australia (Trouillas et al. 2011) and apricot, Japanese plum in South Africa (Moyo et al. 2018). Based on literature reviews, this is the first time that E. citricola has been found on pistachio trees worldwide. In this work, we found E. vitis from two sources, affected branches as well as wood debris of walnut trees. In Iran, this species has previously been reported from grapevine (Jordan and Schilder 2005), persimmon (Jabbari Firoozjah and Mohammadi 2015) and forest trees (Kazemzadeh Chakusari 2017). This study represents the first record of E. vitis on walnut trees worldwide.

Results of our study showed that fruiting bodies of Botryosphaeriaceae species were quite frequent on wood debris. This result is consistent with reported results in studies conducted on forest, fruit and grapevine debris that emphasized the fact the fungi belonging to the Botryosphaeriaceae family survive well on wood debris (Santini et al. 2008). For example, Diplodia sapinea was isolated from pruning debris of Prunus spp. (Damm et al. 2007), N. parvum from flooded gum debris (Perez et al. 2008), N. parvum and Sphaeropsis porosa from grapevine pruning debris (Van Niekerk et al. 
2003, 2004). Hence, wood debris can play important role facilitating overwintering of Botryosphaeriaceae in nut crops orchards, thus being a primary inoculum source to initiate infections.

Preliminary pathogenicity results showed that, all tested isolates caused wood discoloration on detached shoots of almond, pistachio and walnut. But, also revealed significant differences in the degree of virulence among species and among isolates of the same species, which is consistent with results obtained for other fungal trunk pathogens such as Botryosphaeriaceae (Úrbez-Torres and Gubler 2009) and Diatrypaceae species on grapevine (Trouillas and Gubler 2010b; Pitt et al. 2013), and Botryosphaeriaceae and Phaeoacremonium species on forest trees (Kazemzadeh Chakusari et al. 2017, 2019). On almond, D. gallae, L. theobromae and $N$. parvum were the most aggressive species, while Eutypella sp. 1 and $D$. whitmanensis did not produce significantly longer lesions than the controls. The high degree of aggressiveness observed in this study for L. theobromae is consistent with the findings reported by Rodriguez-Galvez et al. (2016) on mango stems in Peru, grapevine in California (Urbez-Torres and Gubler 2009) and peach trees in USA and China (Britton and Hendrix 1989; Wang et al. 2011). Neofusicoccum parvum and N. mediterraneum have been reported the most virulent species on almond trees in Spain (Olmo et al. 2016). Previous studies also showed that N. luteum and N. parvum are highly virulent on avocado (McDonald et al. 2009) and citrus (Adesemoye et al. 2014) in California, and on grapevine in California (Urbez-Torres and Gubler 2009), New Zealand (Billones et al. 2014) and Spain (Luque et al. 2009) and pistachio in Iran (Mohammadi et al. 2015).

Results of the pathogenicity tests on pistachio shoots showed that all inoculated species tested were pathogenic on this host. The lesions caused by Eutypella sp. 2 and one isolate of B. dothidea were longer than those caused by the other isolates. Results of previous studies showed that B. dothidea is one of the main pathogens of pistachio (Michailides 1991) but was reported to be weakly pathogenic to healthy vines, Eucalyptus and Syzygium in South Africa (Van Niekerk et al. 2004; Pavlic et al. 2007; Slippers et al. 2007).

Lasiodiplodia theobromae was the most virulent fungal species and caused the largest lesions on walnut shoots. Our results are consistent with previous pathogenicity studies, in which this species was shown to be one of the most virulent Botryosphaeriaceae species on grapevines (Leavitt 1990; Van Niekerk et al. 2004). According to pathogenicity trials conducted in California, L. theobromae has been reported as an aggressive pathogen on grapevines (Úrbez-Torres et al. 2009). This species is an important wood pathogen, which has been reported from more than 500 plant hosts, including nut trees (Punithalingam 1980, Phillips et al. 2013). The high virulence of $L$. theobromae indicates that this fungus should be considered one of the primary walnut trunk pathogens in Iran.

In summary, the current work represents the first detailed study concerning the isolation, identification and pathogenicity of fungal pathogens associated with branch cankers and trunk diseases on almond, pistachio and walnut, in Iran. Large number of Botryosphaeriaceae, Diatrypaceae and Phaeoacremonium, species were isolated from these hosts, and also more occasionally $C$. hispanica and $P$. richardsiae. New reports of some species in Iran or in new hosts improve 
the current knowledge about the geographical distribution and host range of these species. Preliminary pathogenicity tests demonstrated that most of these fungi were pathogenic to almond, pistachio and walnut shoots. Therefore, more importance should be given to these pathogens in Iran, and specific management strategies should be included within the nut crops IPM management programs, with the aim of improving their sustainability.

\section{Ethical statements}

Funding: The first author is financially supported by the Iranian Ministry of Science, Research and Technology (MSRT) just for her 4 months stay in Spain as a part of her PhD project. However, no funding was received from MSRT for this study by the authors.

Conflict of Interest: The authors declare that they have no conflict of interest.

Informed consent: Informed consent was obtained from all individual participants included in the study.

Ethical approval: This article does not contain any studies with human participants or animals performed by any of the authors.

\section{References}

Abdollahzadeh, J., Javadi, A., Mohmammadi Goltapeh, E., Zare, R., \& Phillips, A. J. L. (2010). Phylogeny and morphology of four new species of Lasiodiplodia from Iran. Persoonia, 25, 1-10.

Abdollahzadeh, J., Zare, R., \& Phillips, A. J. L. (2013). Phylogeny and taxonomy of Botryosphaeria and Neofusicoccum species in Iran, with description of Botryosphaeria scharifii sp. nov. Mycologia, 105, 210-220.

Abdollahzadeh, J., Javadi, A., Zare, R., \& Phillips, A. J. L. (2014). A phylogenetic study of Dothiorella and Spencermatinsia species associated with woody plants in Iran, New Zealand, Portugal and Spain. Persoonia, 32, 112.

Adesemoye, A. O., Mayorquin, J. S., Wang, D. H., Twizeyimana, M., Lynch, S. C., \& Eskalen, A. (2014). Identification of species of Botryosphaeriaceae causing bot gummosis in citrus in California. Plant Disease, 98, 55-61.

Alves, A., Crous, P. W., Correia, A., \& Phillips, A. J. L. (2008). Morphological and molecular data reveal cryptic speciation in lasiodiplodia theobromae. Fungal Diversity, 28, 1-13.

Armengol, J., Vicent, A., Torne, L., Garcia-Figueres, F., \& Garcia-Jimenez, J. (2001). Fungi associated with esca and grapevine declines in Spain: a three-year survey. Phytopathologia Mediterranea, 40, 325-329. 
Armengol, J., Gramaje, D., Perez-Sierra, A., Landeras, E., Alzugaray, R., Luque, J., \& Martos, S. (2008). First report of canker disease caused by Neofusicoccum australe on eucalyptus and pistachio in Spain. Plant Disease, $92,980$.

Aroca, A., García-Figueres, F., Bracamonte, L., Luque, J., \& Raposo R. (2006). A survey of trunk disease pathogens within rootstocks of grapevines in Spain. European Journal of Plant Pathology, 115, 195-202.

Arzanlou, M., Narmani, A., Khodaei, S., \& Moshari, S. (2014). Pome and stone fruit trees as possible reservoir hosts for Phaeoacremonium spp., the causal agents of grapevine esca disease, in Iran. Archives of Phytopathology and Plant Protection, 47, 717-727.

Arzanlou, M., Ghasemi, S., \& Baradaran Bagheri, M. (2016). Collophora hispanica, a new pathogen and potential threat to the almond industry in Iran. Journal of Phytopathology, 164, 833.

Baradaran Bagheri, M., Arzanlou, A., \& Babai-ahari, A. (2015). Identification of the fungal agents associated with almond trunk diseases in East Azerbeijan province. Applied Research on Plant Protection, 4, $27-41$.

Bayazit, S., Kazan, K., Gulbitti, S., Çevik, V., Ayanoglu, H., \& Ergul, A. (2007). AFLP analysis of genetic diversity in low chill requiring walnut (Juglans regia L.) genotypes from Hatay, Turkey. Science of Horticulture, 111, $394-398$.

Begoude, B. A. D., Slippers, B., Wingfield, M. J., \& Roux, J. (2011). The pathogenic potential of endophytic Botryosphaeriaceous fungi on Terminalia species in Cameroon. Forest Pathology, 41, 281-292.

Billones-Baajeins, R., Jones, E. E., Ridgway, H. J., \& Jaspers, M. V. (2014). Susceptibility of common rootstock and scion grapevine varieties in New Zealand to Botryosphaeriaceae species. Australian Plant Pathology, 43, $25-31$.

Britton, K. O., \& Hendrix, F. F. (1989). Infection of peach buds by Botryosphaeria obtusa. Plant Disease, 73, 65-68.

Canale, M. C., Nunes Nesi, C., Falkenbach, B. R., Hunhoff Da Silva, C. A., \& Brugnara, E. C. (2019). Pleurostomophora richardsiae associated with olive tree and grapevine decline in Southern Brazil. Phytopathologia Mediterranea, 58, $201-205$.

Carbone, I., \& Kohn, L. M. (1999). A method for designing primer sets for speciation studies in filamentous ascomycetes. Mycologia, 91, 553-556.

Carlucci A., Raimondo M. L., Cibelli F., Phillips A. J. L., \& Lops, F. (2013). Pleurostomophora richardsiae, Neofusicoccum parvum and Phaeoacremonium aleophilum associated with a decline of olives in southern Italy. Phytopathologia Mediterranea, 52, 517-527.

Carlucci A., Cibelli F., Lops F., Phillips A. J. L., Ciccarone C., \& Raimondo M. L. (2015a). Pleurostomophora richardsiae associated with trunk diseases of grapevine in southern Italy. Phytopathologia Mediterranea, 54, 109123. 
Carlucci, A., Cibelli, F., Lops, F., Luisa, M., \& Raimondo, D. (2015b). Characterization of Botryosphaeriaceae species as causal agents of trunk diseases on grapevines. Plant Disease, 99, 1678-1688.

Carter, M. V. (1982). Additional hosts of Eutypa arrneniacae in Australia. Australasian Plant Pathology, 11, 46-48.

Chen, S. F., Fichtner, E., Morgan, D. P., \& Michailides, T. J. (2013a). First report of Lasiodiplodia citricola and Neoscytalidium dimidiatum causing death of graft union of English walnut in California. Plant Disease, 97, 993.

Chen, S. F., Morgan, D. P., Beede, R. H., \& Michailides, T. J. (2013b). First report of Lasiodiplodia theobromae associated with stem canker of almond in California. Plant Disease, 97, 994.

Chen, S. F., Morgan, D. P., Hasey, J. K., \& Michailides, T. J. (2013c). First report of Lasiodiplodia citricola associated with stem canker of peach in California, USA. Journal of Plant Pathology, 95, 659-659.

Chen, S. F., Morgan, D. P., Hasey, J. K., Anderson, K., \& Michailides, T. J. (2014a). Phylogeny, morphology, distribution, and pathogenicity of Botryosphaeriaceae and Diaporthaceae from English walnut in California. Plant Disease, 98, $636-652$.

Chen, S. F., Morgan, D. P., \& Michailides, T. J. (2014b). Botryosphaeriaceae and Diaporthaceae associated with panicle and shoot blight pistachio in California, USA. Fungal Diversity, 67, 157-179.

Chen, S. F.,Li, G. Q., Liu, F. F., \& Michailides, T. J. (2015). Novel species of Botryosphaeriaceae associated with shoot blight of pistachio. Mycologia, 107, 780-792.

Chicau, G., Aboim-Inglez, M., Cabral, S., \& Cabral, J. P. S. (2000). Phaeoacremonium chlamydosporum and Phaeoacremonium angustius associated with esca and grapevine decline of Vinho verde grapevines in Northwest Portugal. Phytopathologia Mediterranea, 39, 80-86.

Cloete, M., Fourie, P. H., Damm, U., Crous, P. W., \& Mostert, L. (2011). Fungi associated with dieback symptoms of apple and pear trees with a special reference to grapevine trunk disease pathogens. Phytopathologia Mediterranea, $50,176-190$.

Croghan, C. F., \& Robbins, K. (1986). Cankers caused by Botryodiplodia gallae associated with oak sprout mortality in Michigan. Plant Disease, 70, 76-77.

Crous, P. W., Gams, W., Wingfield, M. J., \& van Wyk, P. S. (1996). Phaeoacremonium gen. nov. associated with wilt and decline diseases of woody hosts and human infections. Mycologia, 88, 786-796.

Damm, U., Crous, P. W., \& Fourie, P. H. (2007). Botryosphaeriaceae as potential pathogens of Prunus species in South Africa, with descriptions of Diplodia africana and Lasiodiplodia plurivora sp. nov. Mycologia, 99, 664-680.

Damm, U., Mostert, L., Crous, P. W., \& Fourie, P. H. (2008). Novel Phaeoacremonium species associated with necrotic wood of Prunus trees. Persoonia, 20, 87-102. 
Damm, U., Fourie, P. H., \& Crous, P. W. (2010). Coniochaeta (Lecythophora), Collophora gen. nov. and Phaeomoniella species associated with wood necroses of Prunus trees. Persoonia, 24, 60-80.

Dissanayake, A. J., Phillips, A. J. L., Li, X. H., \& Hyde, K. D. (2016). Botryosphaeriaceae: Current status of genera and species. Mycosphere, 7, 1001-1073.

Doll, D. A., Rolshausen, P. E., Pouzoulet, J., \& Michailides, T. J. (2015). First report of Dothiorella iberica causing trunk and scaffold cankers of almond in California. Plant Disease, 99, 1185.

Doyle, J. J., \& Doyle, J. L. (1990). Isolation of plant DNA from fresh tissue. Focus, 12, 13-15.

Dupont, J., Laloui, W., Magnin, S., Larignon, P., \& Roquebert, M. F. (2000). Phaeoacremonium viticola, a new species associated with esca disease of grapevine in France. Mycologia, 92, 499-504.

Eichmeier, A., Pecenka, J., Necas, T., Ondrasek, I., Armengol, J., Leon, M., Berlanas, C., \& Gramaje, D. (2019). Fungal trunk pathogens associated with Juglans regia in the Czech Republic. Plant Disease, https://doi.org/10.1094/PDIS06-19-1308-RE.

Ellis, M. B., \& Ellis, J. P. (1997). Microfungi on land plants: An identification handbook. The Richmond Publishing Co., New York, 818pp.

English, H., Davis, J. R., \& DeVay, J. E. (1966). Dothiorella canker, a new disease of almond trees in California. Phytopathology, 56, 146.

Ershad, J. (2009). Fungi of Iran. Iranian Research Institute of Plant Protection, 558pp.

Essakhi, S., Mugnai, L., Crous, P. W., Groenewald, J. Z., \& Surico, G. (2008). Molecular and phenotypic characterization of novel Phaeoacremonium species isolated from esca diseased grapevines. Persoonia, 21, 119-134.

FAOSTAT (2018). Food and Agriculture Organization of the United Nations. http://www.fao.org/faostat/es/\#dat.

Felsenstein, J. (1985). Confidence limits on phylogenies: an approach using the bootstrap. Evolution, 39,783-791.

Garcia-Benavides, B., Martin-Zamorano, P., Ocete-Perez, C. A., Maistrello, L., \& Ocete-Rubio, R. (2013). Biodiversity of pathogenic wood fungi isolated from Xylotrechus arvicola (Olivier) galleries in vine shoots. Journal International des Sciences de la Vigne et du Vin, 47, 73-81.

Gierl, L., \& Fischer, M. (2017). Grapevine trunk disease in German viticulture II. Associated fungi occurring on nonVitis hosts, and first report of Phaeoacremonium angustius. Vitis, 56, 103-110.

Glass, N. L., \& Donaldson, G. C. (1995). Development of primer sets designed for use with the PCR to amplify conserved genes from filamentous ascomycetes. Applied and Environment Microbiology, 61, 1323-1330.

Glawe, D. A. (1984). Cryptosphaeria pullmanensis, a new species from Washington state. Mycologia, 76, $166-169$.

Glawe, D. A., \& Rogers, J. D. (1984). Diatrypaceae in the Pacific Northwest. Mycotaxon, 20, 401-460. 
Gramaje, D., Alaniz, S., Pérez-Sierra, A., Abad-Campos, P., García-Jiménez, J., \& Armengol, J. (2008). First report of Phaeoacremonium scolyti causing Petri disease of grapevine in Spain. Plant Disease, 92, 835.

Gramaje, D., Armengol, J., Mohammadi. H., Banihashemi, Z., \& Mostert, L. (2009). Novel Phaeoacremonium species associated with Petri disease and esca of grapevine in Iran and Spain. Mycologia, 101, 920-929.

Gramaje, D., Agustí-Brisach, C., Pérez-Sierra, A., Moralejo, E., Olmo, L., Mostert, L. et al. (2012). Fungal trunk pathogens associated with wood decay of almond trees on Mallorca (Spain). Persoonia, 28, 1-13.

Gramaje, D., Mostert, L., Groenewald, J. Z., \& Crous, P. W. (2015). Phaeoacremonium: from esca disease to phaeohyphomycosis. Fungal Biology, 119, 759-783.

Gramaje, D., Baumgartner, K., Halleen, F., Mostert, L., Sosnowsk, M. R., Urbez-Torres, J. R., \& Armengol, J. (2016). Fungal trunk diseases: a problem beyond grapevines? Plant Pathology, 65, 355-356.

Groenewald, M., Kang, J. C., Crous, P.W., \& Gams, W. (2001). ITS and betatubulin phylogeny of Phaeoacremonium and Phaeomoniella species. Mycological Research, 105, 651-657.

Haggag, W. M., Abou Rayya, M. S. M., \& Kasim, N. E. (2007). First report of a canker disease of walnut caused by Botryodiplodia theobromae in Egypt. Plant Disease, 91, 226.

Halleen, F., Mostert, L., \& Crous, P. W. (2007). Pathogenicity testing of lesser known vascular fungi of grapevines. Australasian Plant Pathology, 36, 277-285.

Hamrouni, N., Nouri, M.T., Trouillas, F.P., Said, A., Sadfi-Zouaoui, N., \& Hajlaoui, M. R. (2018). Dothiorella gummosis caused by Dothiorella viticola, first record from citrus in Tunisia. New Disease Reports, 38, 10.

Hashemi, H., Mohammadi, H., \& Abdollahzadeh, J. (2017). Symptoms and fungi associated with elm trees decline in Iran. European Journal of Forest Research, 136, 857-879.

Hennion, B., Baudry, A., Lecomte, P., Durpaire, M. P., Mouyon, M., Tailleur, J. L., \& Larignon, P. (2001). Deperissement du kiwi par maladie du bois. Infos-Ctifl, 176, 25-27.

Holland, L. A., Nouri, M. T., Crespo, M. P., Holtz, B. A., Yaghmour, M. A., Doll, D. A., \& Trouillas, F. P. (2018). First report of Collophora hispanica and Collophora paarla causing branch cankers of almond in California. Plant Disease, 102, 1663.

Inderbitzin, P., Bostock, R. M., Trouillas, F. P., \& Michailides, T. J. (2010). A six locus phylogeny reveals high species diversity in Botryosphaeriaceae from California almond. Mycologia, 102, 1350-1368.

Jabbari Firoozjah, M., \& Mohammadi, H. (2015). First report of Eutypella vitis associated with persimmon trees in Iran. Plant Disease, 99, 1181.

Jordan, S., \& Schilder, A. (2005). Eutypella vitis, a potential pathogen of grapevines in Michigan. (Abstract) Phytopathology, 95, 51. 
Kazemzadeh Chakusary, M. (2017). Etiology and distribution of forest trees decline in Guilan province with emphasis on isolation and identification of Phaeoacremonium and Botryosphaeriaceae species and the potential role of woody debris on the survival of the pathogens. Ph.D. Dissertation. Shahid Bahonar University of Kerman, Kerman, Iran, 300 pp.

Kazemzadeh Chakusary, M., Mohammadi, H., \& Khodaparast, S. A. (2017). Decline-associated Phaeoacremonium species occurring on forest trees in the north of Iran. Forest Pathology, 47, 1-15.

Kazemzadeh Chakusary, M., Mohammadi, H., \& Khodaparast, S. A. (2019). Diversity and pathogenicity of Botryosphaeriaceae species on forest trees in the north of Iran. European Journal of Forest Research, 138, 685704.

Kumar, S., Stecher, G., Li, M., Knyaz, Ch., \& Tamura, K. (2018). MEGA X: Molecular evolutionary genetics analysis across computing platforms. Molecular Biology and Evolution, 35, 1547-1549.

Leavitt, G. M. (1990). The occurrence, distribution, effects and control of Botryodipodia theobromae on Vitis vinifera in California, Arizona and northern Mexico. Ph.D. dissertation, University of California, Riverside.

Li, G. Q., Liu, F. F., Li, J. Q., Liu, Q. L., \& Chen, S. F. (2016). Characterization of Botryosphaeria dothidea and Lasiodiplodia pseudotheobromae from English Walnut in China. Journal of Phytopathology, 164, 348-353.

Luque, J., Martos, S., Aroca A., Raposo, R., \& Garcia-Figueres, F. (2009). Symptoms and fungi associated with declinin mature grapevine in northeast Spain. Journal of Plant Pathology, 91, 381-390.

Ma, R., Zhu, Y. F., Fan, X. L., \& Tian, C. M. (2016). Canker disease of willow and poplar caused by Cryptosphaeria pullmanensis recorded in China. Forest Pathology, 46, 327-335.

Marín-Terrazas, M., Ramos-Sáez de Ojer, J. L., López-Manzanares, B., \& Gramaje, D. (2016). First report of Phaeoacremonium minimum causing wood decay in nursery plants of almond in Spain. Plant Disease, 100, 1244.

Mayorquin, J., Wang, D., Twizeyimana, M., \& Eskalen, A. (2016). Identification, distribution and pathogenicity of Diatrypaceae and Botryosphaeriaceae associated with citrus branch canker in the Southern California desert. Plant Disease. 100, 2402-2413.

McDonald, V., Lynch, S., \& Eskalen, A. (2009). First report of Neofusicoccum australe, N. luteum, and N. parvum associated with avocado branch canker in California. Plant Disease, 93, 967.

McGranahan, G. H., \& Leslie, C. (1991). Walnuts ‘Juglans regia’. Acta Horticulturae, 290, 901-951.

Michailides, T. J. (1991). Pathogenicity, distribution, sources of inoculum, and infection courts of Botryosphaeria dothidea on pistachio. Phytopathology, 81, 566-573.

Michailides, T. J., \& Morgan, D. P. (2004). Panicle and shoot blight of pistachio: a major threat to the California pistachio industry. APS net Feature, DOI: 10.1094/APSnetFeature-2004-0104. 
Miller, M. A., Pfeiffer, W., \& Schwartz, T. (2010). Creating the CIPRES Science Gateway for Inference of Large Phylogenetic Trees. SC10 Workshop on Gateway Computing Environments (GCE10), pp.1-10.

Mohammadi, H. (2011). First report of Phaeoacremonium mortoniae associated with grapevine decline in Iran. Plant Disease, 95, 1043.

Mohammadi, H. (2012). First report of Phaeoacremonium tuscanum causing Petri disease of grapevine in Iran. New Disease Report, 25, 21.

Mohammadi, H., Ezati, Gh., \& Alaei, H. (2013). Diplodia seriata and Phaeoacremonium species associated with walnut trees showing dieback symptoms in Ardabil province. $1^{\text {th }}$ Iranian Mycological Congress, Rasht, Iran, 102p.

Mohammadi, H. (2014). Phaeoacremonium spp. and Botryosphaeriaceae spp. associated with date palm (Phoenix dactylifera L.) decline in Iran. Journal of Phytopathology, 162, 575-581.

Mohammadi, H., Kazemi, S., \& Farahmand, H. (2014). Phaeoacremonium and Botryosphaeriaceae species associated with cypress (Cupressus sempervirens L.) decline in Kerman province (Iran). Phytopathologia Mediterranea, 53, $27-39$.

Mohammadi, H., Sarcheshmehpour, M., \& Mafi, E. (2015). Fungal trunk pathogens associated with wood decay of pistachio trees in Iran. Spanish Journal of Agricultural Research, 13, 10 pp.

Mohammadi, H., \& Sharifi, S. (2016). Association of Botryosphaeriaceae and Phaeoacremonium species with insectdamaged quince shoots. Journal of Plant Pathology, 98, 31-38.

Moral, J., Muñoz-Díez, C., González, N., Trapero, A., \& Michailides, T. J. (2010). Characterization and pathogenicity of Botryosphaeriaceae species collected from olive and other hosts in Spain and California. Phytopathology, 100, $1340-1351$.

Moral, J., Morgan, D., Trapero, A., \& Michailides, T. J. (2019). Ecology and epidemiology of diseases of nut crops and olives caused by Botryosphaeriaceae fungi in California and Spain. Plant Disease, 103, 1809-1827.

Mostert, L., Halleen, F., Creaser, M. L., \& Crous, P. W. (2004). Cryptovalsa ampelina, a forgotten shoot and cane pathogen of grapevines. Australasian Plant Pathology, 33, 295-299.

Mostert, L., Groenewald, J. Z., Summerbell, R. C., Gams, W., \& Crous, P. W. (2006). Taxonomy and pathology of Togninia (Diaporthales) and its Phaeoacremonium anamorphs. Studies in Mycology, 54, 1-115.

Mousavi M., Mohammadi H., \& Soltaninejad N. (2014). First report of Phaeoacremonium minimum (Ascomycota, Calosphaeriales) on almond and cherry trees in Kerman province. 21th Iranian Plant Protection Congress, Urmia, Iran, pp. 28. 
Moyo, P., Damm, U., Mostert, L., \& Halleen, F. (2018). Eutypa, Eutypella and Cryptovalsa species (Diatrypaceae) associated with Prunus species in South Africa. Plant Disease, 102, 1402-1409.

Nouri M. T., Lawrence D. P., Yaghmour M. A., Michailides T. J., \& Trouillas, F. P. (2018). Neoscytalidium dimidiatum causing canker, shoot blight and fruit rot of almond in California. Plant Disease, 102, 1638-1647.

Olmo, D., Armengol, J., León, M., \& Gramaje, D. (2015). Pathogenicity testing of lesser-known fungal trunk pathogens associated with wood decay of almond trees. European Journal of Plant Pathology, 143, 607-611.

Olmo, D., Armengol, J., León, M., \& Gramaje, D. (2016). Characterization and pathogenicity of Botryosphaeriaceae species isolated from almond trees on the Island of Mallorca (Spain). Plant Disease, 100, 2483-2491.

Panahandeh, S., Mohammadi, H., \& Gramaje, D. (2019). Trunk disease fungi associated with Syzygium cumini in Iran. Plant Disease, 103, 711-720.

Pavlic, D., Slippers, B., Coutinho, T. A., \& Wingfield, M. J. (2007). The Botryosphaeriaceae occurring on Syzygium cordatum in South Africa, and their potential threat to Eucalyptus. Plant Pathology, 56, 624-636.

Pérez, C. A., Altier, N., Simeto, S., Wingfield, M. J., Slippers, B., \& Blanchette, R. A. (2008). Botryosphaeriaceae from Eucalyptus and native Myrtaceae in Uruguay. Agrociencia, 12, 19-30.

Phillips, A. J. L., Alves, A., Abdollahzadeh, J., Slippers, B., Wingfield, M. J., Groenewald, J. Z., \& Crous, P. W. (2013). The Botryosphaeriaceae: genera and species known from culture. Studies in Mycology, 76, 51-167.

Pitt, W. M., Huang, R., Trouillas, F. P., Savocchia, S., \& Steel, C. C. (2009). Evidence that Eutypa lata and other diatrypaceous species occur in New South Wales vineyards. Australasian Plant Pathology, 39, 97-106.

Pitt, W. M., Trouillas, F. P., Gubler, W. D., Savocchia, S., \& Sosnowski, M. R. (2013). Pathogenicity of diatrypaceous species on grapevine in Australia. Plant Disease, 97, 749-756.

Punithalingam, E. (1980). Plant diseases attributed to Botryodiplodia theobromae. In: Biblioteca Mycologica. J. Cramer, Berlin.

Raoufi, F., Banihashemi, Z., \& Mirtalebi, M. (2016). First report of walnut canker caused by Cryptosphaeria pullmanensis in Iran. 22nd Iran Plant Protection Congress, 27-30 August.

Rodriguez-Galvez, E., Guerrero, P., Barradas, C., Crous, P.W., \& Alves, A. (2016). Phylogeny and pathogenicity of Lasiodiplodia species associated with dieback of mango in Peru. Fungal Biology, 121, 452-465.

Rolshausen, P. E., Úrbez-Torres, J. R., Rooney-Latham, S., Eskalen, A., Smith, R. J., \& Gubler, W. D. (2010). Evaluation of pruning wound susceptibility and protection against fungi associated with grapevine trunk diseases. American Journal of Enology and Viticulture, 61, 113-119. 
Rooney-Latham, S., Escalen, A., \& Gubler, W. D. (2005) Teleomorph formation of Phaeoacremonium aleophilum, cause of esca and grapevine decline in California. Plant Disease, 89, 177-184.

Rumbos, I. (1984). Damages caused by the fungus Eutypa arrneniacae. Geotechnica, 4, 118-125.

Rumbos, I. (1986). Isolation and identification of Eutypa lata from Pistacia vera in Greece. Journal of Phytopathology, $116,352-357$.

Sami, S., Mohammadi, H., \& Heydarnejad. J. (2014). Phaeoacremonium species associated with necrotic wood of pome fruit trees in Iran. Journal of Plant Pathology, 96, 487-495.

Santini, A., Pepori, A., Ghelardini, L., \& Capretti, P. (2008). Persistence of some pine pathogens in coarse woody debris and cones in a Pinus pinea forest. Forest Ecology and Management, 256, 502-506.

Sessa, L., Abreo, E., Betucci, L., \& Lupo, S. (2016). Botryosphaeriaceae species associated with wood diseases of stone and pome fruits trees: symptoms and virulence across different hosts in Uruguay. European Journal of Plant Pathology, 146, 519-530.

Slippers, B., Smit, W. A., Crous, P. W., Coutinho, T. A., Wingfield, B. D., \& Wingfield, M. J. (2007). Taxonomy, phylogeny and identification of Botryosphaeriaceae associated with pome and stone fruit trees in South Africa and other regions of the world. Plant Pathology, 56, 128-139.

Slippers, B., Boissin, E., Phillips, A. J. L., Groenewald, J. Z., Lombard, L., Wingfield, M. J., Postma, A., Burgess, T., \& Crous, P. W. (2013). Phylogenetic lineages in the Botryosphaeriales: a systematic and evolutionary framework. Studies in Mycology, 76, 31-49.

Soltaninejad, N., Mohammadi, H., \& Massumi, H. (2017). Isolation, identification and pathogenicity of Botryosphaeriaceae and Phaeoacremonium species associated with decline of Prunus species in Iran. Journal of Plant Pathology, 99, 571-581.

Spies, C. F. J., Moyo, P., Halleen, F., \& Mostert, L. (2018). Phaeoacremonium species diversity on woody hosts in the Western Cape province of South Africa. Persoonia, 40, 26-62.

Stamatakis, A. (2014). RAxML version 8: a tool for phylogenetic analysis and post-analysis of large phylogenies. Bioinformatics, 30, 1312-1313.

Templeton, M. D., Rikkerink, E. H., Solon, S. L., \& Crowhurst, R. N. (1992). Cloning and molecular characterization of the glyceraldehyde-3-phosphate dehydrogenase-encoding gene and cDNA from the plant pathogenic fungus Glomerella cingulata. Gene, 122, 225-230.

Teviotdale, B. L., Michailides, T. J., \& Pscheidt, J. W. (2002). Compendium of nut crop diseases in temperate zones. Ed. The American Phytopathological Society. St. Paul, Minnesota, 89 pp. 
Thompson, J. D., Higgins, D. G., \& Gibson, T. J. (1994). Clustral W: improving the sensitivity of progressive multiple sequence alignment through sequence weighting, position-specific gap penalties and weight matrix choice. Nucleic Acids Research, 22, 4673-4680.

Travadon, R., Lawrence, D. P., Rooney-Latham, S., Gubler, W., Wilcox, W. F., Rolshausen, P. E., \& Baumgartner, K. (2015). Cadophora species associated with wood-decay of grapevine in North America. Fungal Biology, 119, 5366.

Trouillas, F. P., \& Gubler, W. D. (2004). Identification and characterization of Eutypa leptoplaca, a new pathogen of grapevine in Northern California. Mycological Research, 108, 1195-1204.

Trouillas, F. P., \& Gubler, W. D. (2010a). Host range, biological variation and phylogenetic diversity of Eutypa lata in California. Phytopathology, 100, 1048-1056.

Trouillas, F. P., \& Gubler, W. D. (2010b). Pathogenicity of Diatrypaceae species in grapevines in California. Plant Disease, 94, 867-872.

Trouillas, F. P., Peduto, F., Inderbitzin, P., \& Gubler W. D. (2015). The genus Cryptosphaeria in the western United States: taxonomy, multilocus phylogeny and a new species, C. multicontinentalis. Mycologia, 107, 1304-1313.

Trouillas, F. P., \& Gubler, W. D. (2016). Cryptosphaeria dieback of fremont cottonwood caused by Cryptosphaeria pullmanensis and C. multicontinentalis in California. Plant Disease, 100(4), 777-783.

Trouillas, F. P., Urbez-Torres, J. R., \& Gubler, W. D. (2010a). Diversity of diatrypaceous fungi associated with grapevine canker diseases in California. Mycologia, 102, 319-336.

Trouillas, F. P., Úrbez-Torres, J. R., Peduto, F., \& Gubler, W. D. (2010b). First report of twig and branch dieback of English walnut (Juglans regia) caused by Neofusicoccum mediterraneum in California. Plant Disease, 94, 1267.

Trouillas, F. P., Pitt, W. M., Sosnowski, M. R., Huang, R., Peduto, F., Loschiavo, A., Savocchia, S., Scott, E. S., \& Gubler, W. D. 2011. Taxonomy and DNA phylogeny of Diatrypaceae associated with Vitis vinifera and other woody plants in Australia. Fungal Diversity, 49, 203-223.

Úrbez-Torres, J. R., Gubler, W. D., \& Luque, J. (2007). First report of Botryosphaeria iberica and B. viticola associated with grapevine decline in California. Plant Disease, 91, 772.

Urbez-Torres, J. R., \& Gubler, W. D. (2009). Pathogenicity of Botryosphaeriaceae species isolated from grapevine cankers in California. Plant Disease, 93, 584-592.

Úrbez-Torres, J. R., Adams, P., Kamas, J., \& Gubler, W. D. (2009). Identification, incidence and pathogenicity of fungal species associated with grapevine dieback in Texas. American Journal of Enology and Viticulture, 60, $497-507$. 
Úrbez-Torres, J. R., Peduto, F., Vossen, P. M., Krueger, W. H., \& Gubler, W. D. (2013). Olive twig and branch dieback: etiology, incidence, and distribution in California. Plant Disease, 97, 231-244.

Úrbez-Torres, J. R., Boule, J., \& O'Gorman, D. T. (2016). First report of Diplodia seriata and D. mutila causing apple dieback in British Columbia. Plant Disease, 100, 1243-1244.

Vaidya,G. D., Lohman, J., \& Meier, R. (2011). SequenceMatrix: concatenation software for the fast assembly of multigene datasets with character set and codon information. Cladistics, 27, 171-180.

Van der Linde, J. A., Six, D. L., Wingfield, M. J., \& Roux, J. (2011). Lasiodiplodia species associated with dying Euphorbia ingens in South Africa. Southern Forests, 73, 165-173.

Van Niekerk, J. M., Crous, P. W., Fourie, P. H., Groenewald, J. Z., \& Halleen, F. (2003). Botryosphaeria canker and dieback of grapevines. 8th international congress of plant pathology, 1-2 Feb., Christchurch, New Zealand, pp 339.

Van Niekerk, J. M., Crous, P. W., Groenewald, J. Z., Fourie, P. H., \& Halleen, F. (2004). DNA phylogeny, morphology and pathogenicity of Botryosphaeria species on grapevines. Mycologia, 96, 781-798.

Van Niekerk, J. M., Fourie, P. H., Halleen, F., \& Crous, P. W. (2006). Botryosphaeria spp. as grapevine trunk disease pathogens. Phytopathologia Mediterranea, 45, 43-54.

Varela, C. P., Fernandez, R., Casal, O. A., Martinez, V. F., \& Vazquez, J. P. M. (2016). First report of Pleurostoma richardsiae causing grapevine trunk disease in Spain. Plant Disease, 100, 2168.

Vezvaei, A. (2003). Isozyme diversity in Iranian almond. Acta Horticulturae, 622, 451-456.

Vijaykrishna, D., Mostert, L., Jeewon, R., Gams, W., Hyde, K. D., \& Crous, P. W. (2004). Pleurostomophora, an anamorph of Pleurostoma (Calosphaeriales), a new anamorph genus morphologically similar to Phialophora. Studies in Mycology, 50, 387-395.

Wang, F., Zhao, L., Li, G., Huang, J., \& Hsiang, T. (2011). Identification and characterization of Botryosphaeria spp. causing gummosis of peach trees in Hubei province, Central China. Plant Disease, 95, 1378-1384.

White, T. J., Bruns, T., Lee, S. J. W. T., \& Taylor, J. L. (1990). Amplified and direct sequencing of fungal ribosomal RNA genes for phylogenies. In: Innis MA, Gelfand DH, Sninsky JJ, White TJ (eds) PCR protocols: A guide to methods and applications (pp. 315-322). Academic, SanDiego.

White, C. L., Halleen, F., Fischer, M., \& Mostert, L. (2011). Characterisation of the fungi associated with esca diseased grapevines in South Africa. Phytopathologia Mediterranea, 50, 204-223.

Yang, T., Groenewald, G. Z., Cheewangkoon,R., Jami, F., Abdollahzadeh, J., Lombard, L., \& Crous, P. W. (2017). Families, genera, and species of Botryosphaeriales. Fungal Biology, 121, 322-346. 
Yu, Z., Tang, G., Peng, S., Chen, H., \& Zhai, M. (2015). Neofusicoccum parvum causing canker of seedlings of Juglans regia in China. Journal of Forestry Research, 26, 1019-1024. 


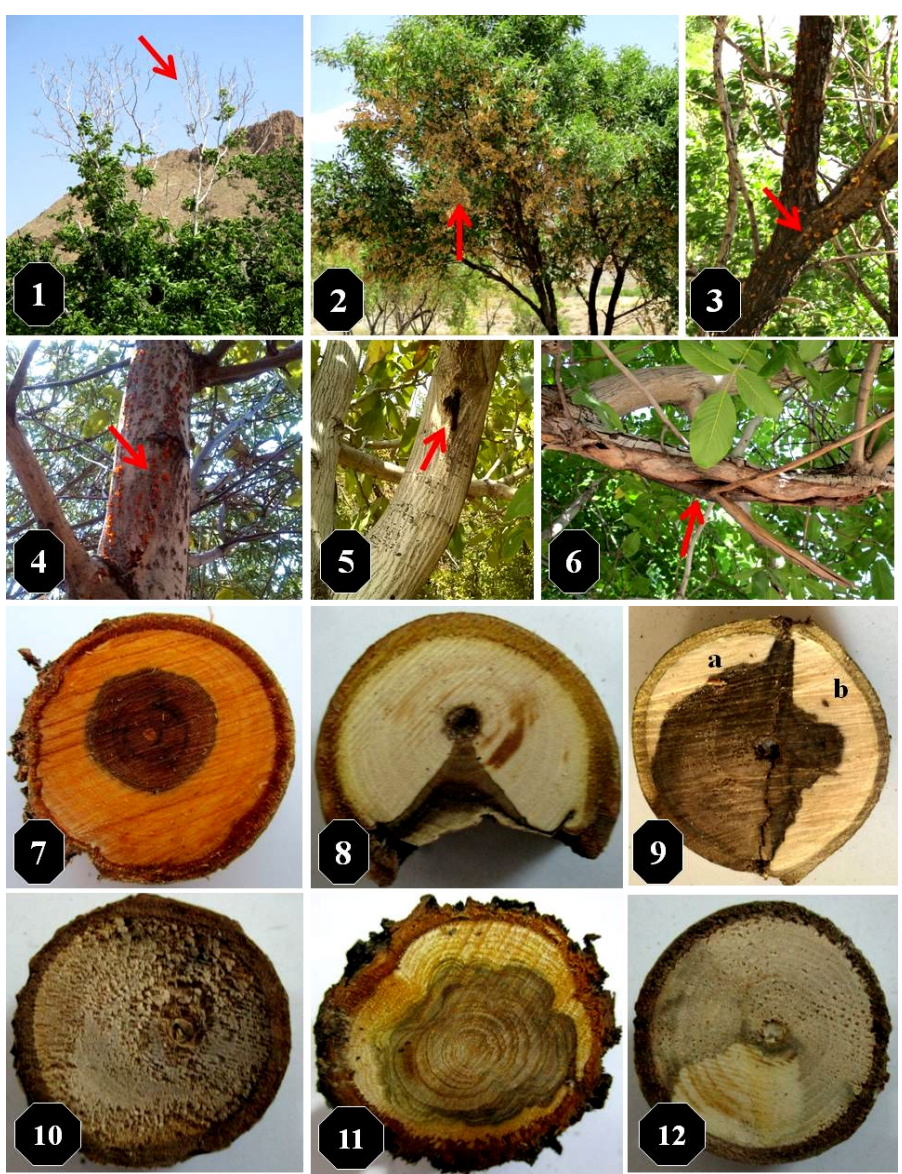

Fig. 1 Main branch canker and trunk disease symptoms found on nut trees (almond, pistachio and walnut). (1-6) external disease symptoms, 1) branch dieback on walnut, 2) yellowing on almond, 35) gumming, 3 on almond, 4 and 5 on walnut, 6) branch canker on walnut, (7-12) internal disease symptoms, 7) central necrosis on almond, 8) v-shaped necrosis on walnut, 9) co-occurrence of irregular wood necrosis (a) and black spot (b) on walnut, 10) wood decay on walnut, 11) brown to black wood streaking on almond, 12) watery necrosis on walnut.

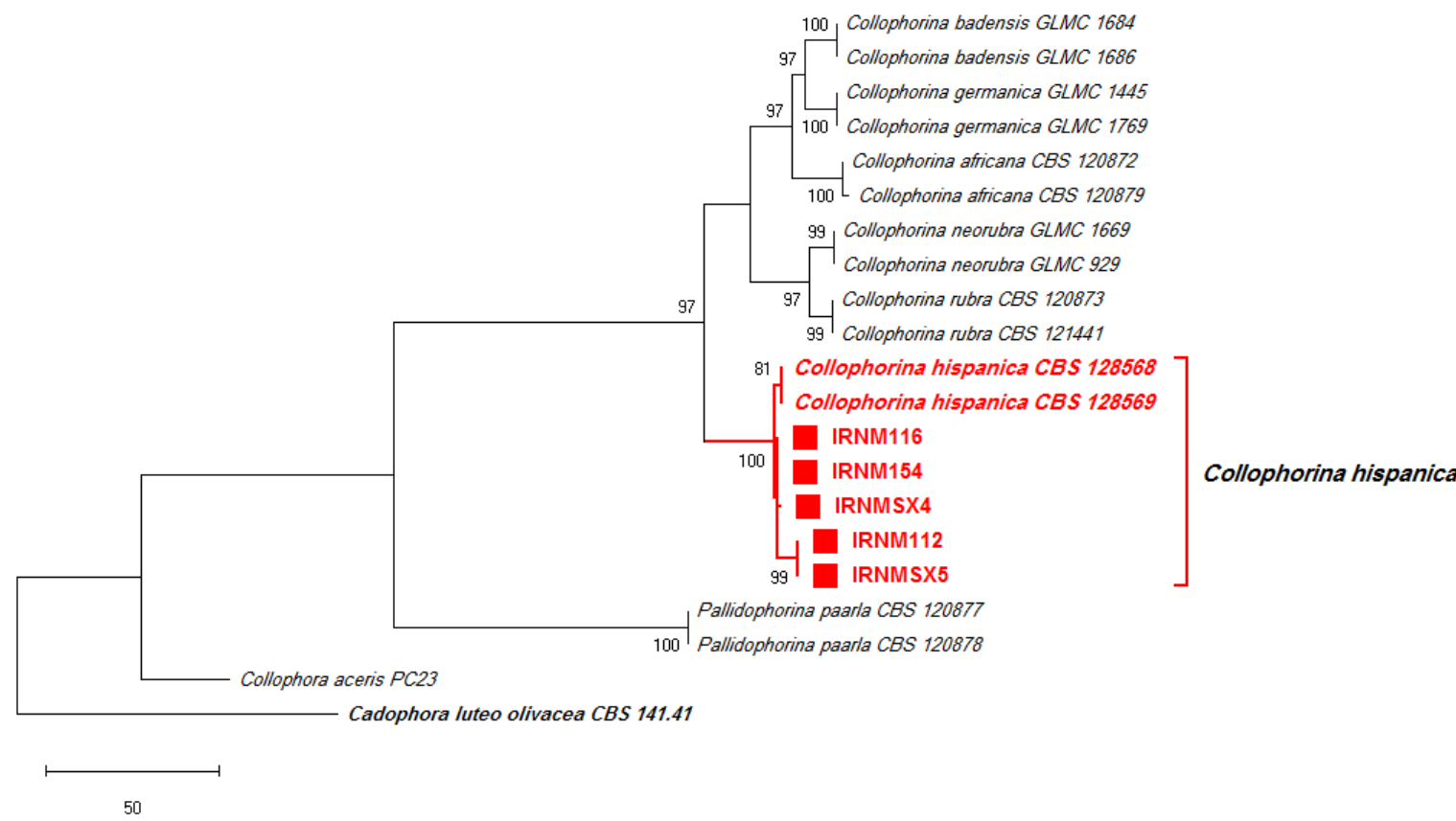

Fig. 2 One of the most parsimonious trees for Collophorina obtained from combined ITS and tef sequence data. Bootstrap support (1000 replicates) above $70 \%$ are shown at the nodes. Cadophora luteo olivacea (CBS141.41) was used as outgroup and Iranian isolates obtained in this study shown in red color. Bar represents 50 changes. 


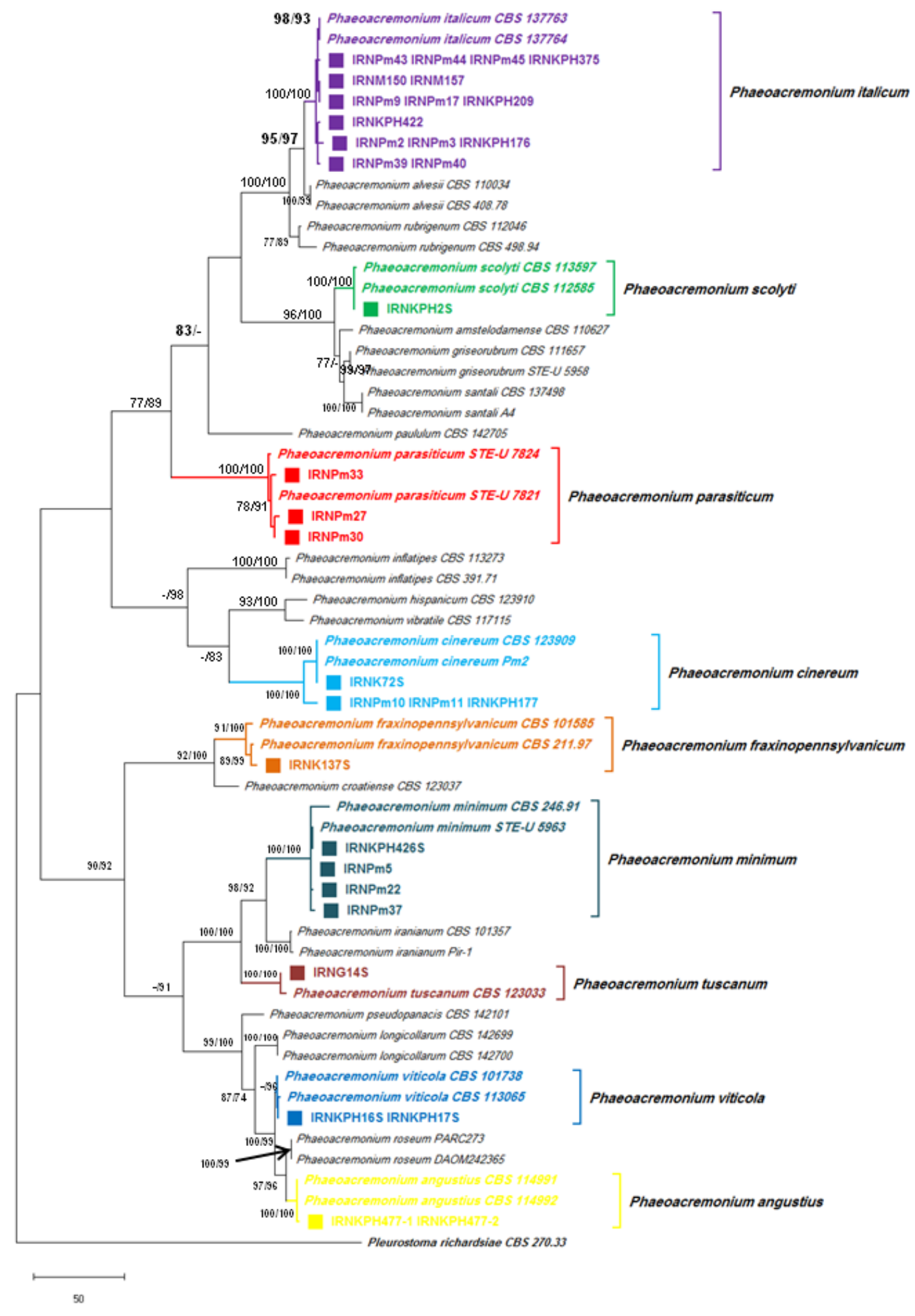

Fig. 3 One of the most parsimonious trees for Phaeoacremonium obtained from combined BT and ACT sequence data. ML/MP bootstrap support (1000 replicates) above $70 \%$ are shown at the nodes. Pleurostoma richardsiae (CBS 270.33) was used as outgroup and Iranian isolates obtained in this study shown in color. Bar represents 50 changes. 


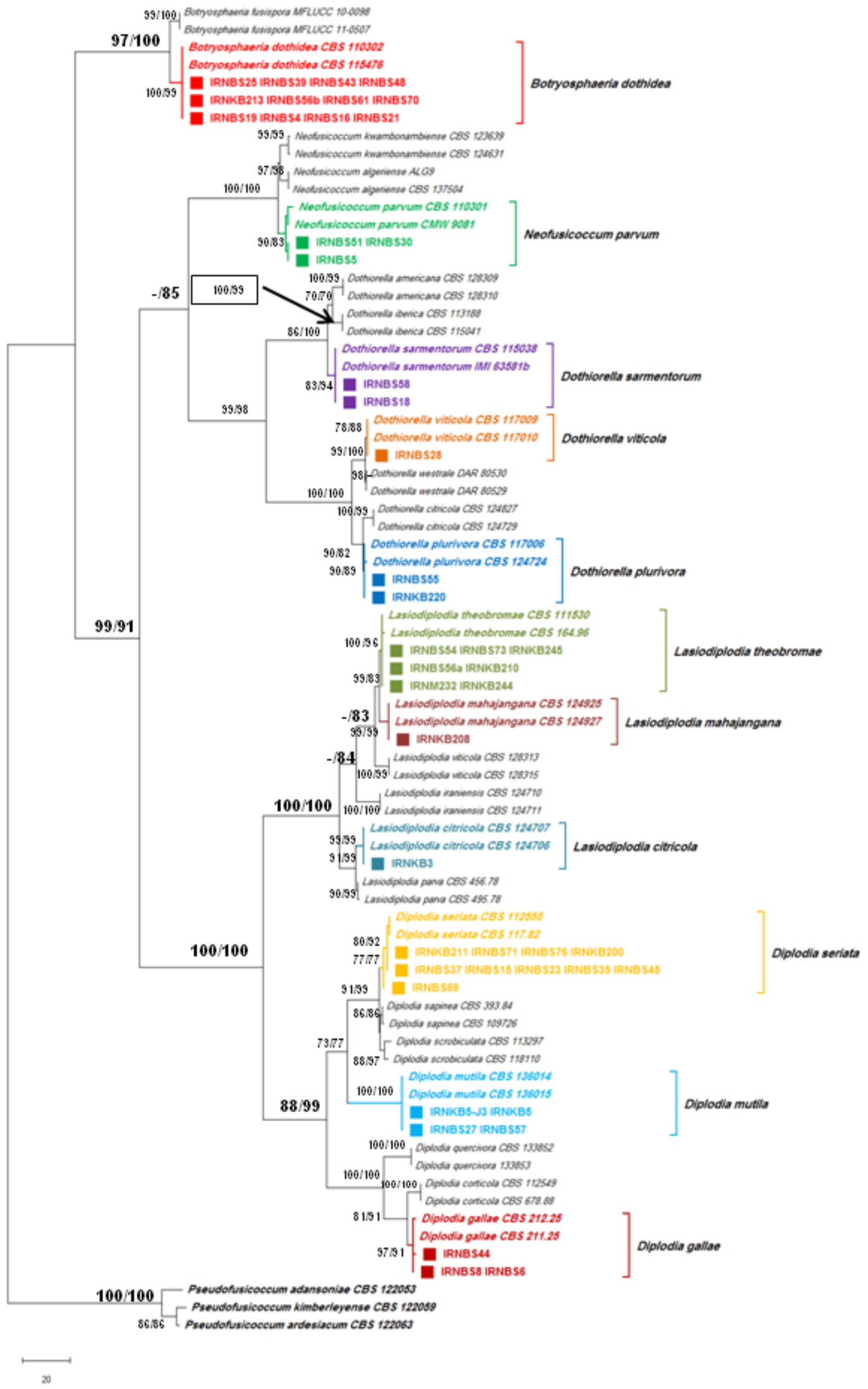

Fig. 4 One of the most parsimonious trees for Botryosphaeriaceae obtained from combined ITS and tef sequence data. ML/MP bootstrap support (1000 replicates) above $70 \%$ are shown at the nodes. Pseudofusicoccum adansoniae (CBS 22055), P. ardesiacum (CBS 122062) and P. kimberleyense (CBS 122058) was used as outgroups and Iranian isolates obtained in this study shown in color. Bar represents 20 changes 


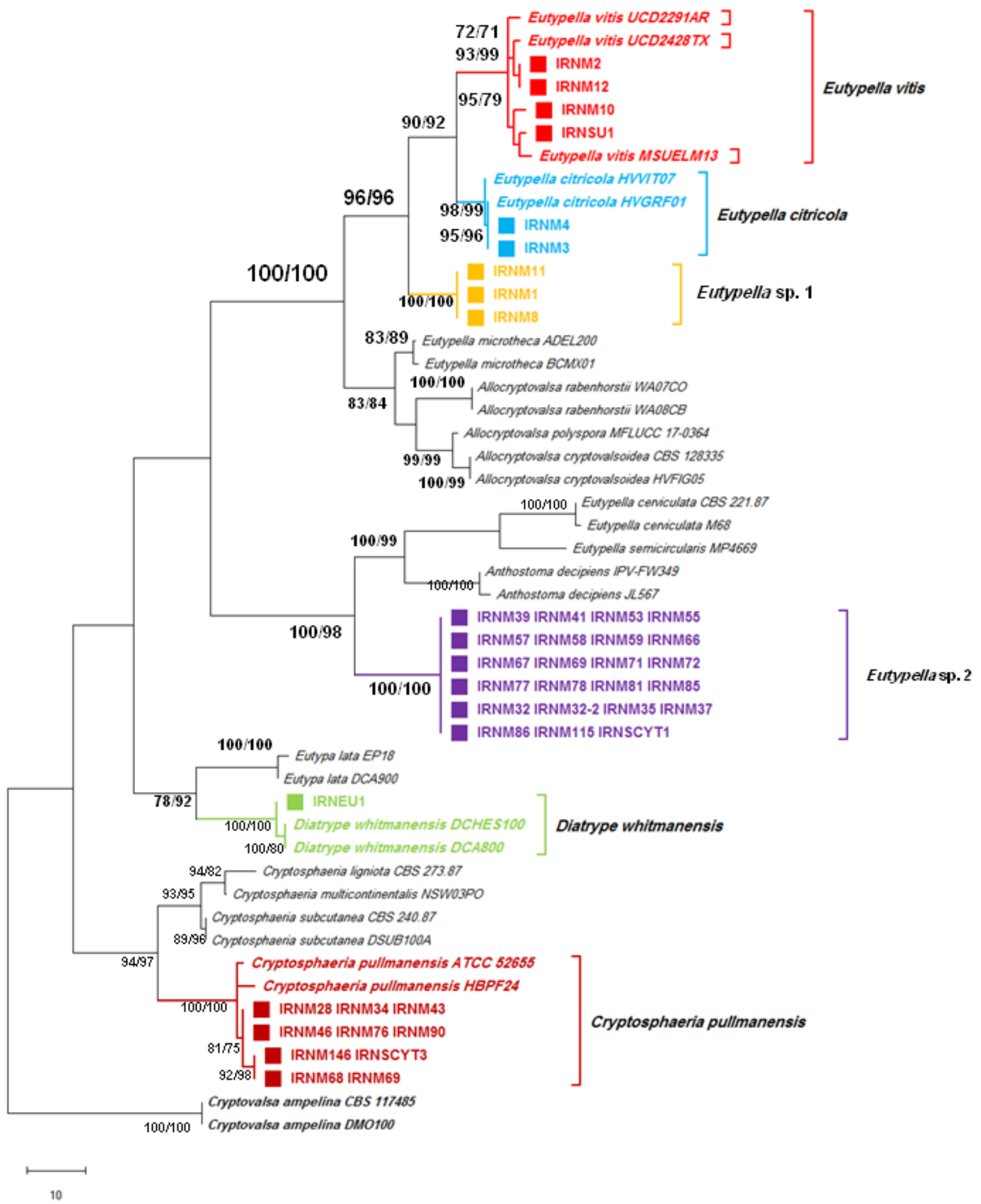

Fig. 5 One of the most parsimonious trees for Diatrypaceae obtained from ITS sequence data. ML/MP bootstrap support (1000 replicates) above $70 \%$ are shown at the nodes. Cryptovalsa ampelina (CBS 117485, DMO100) was used as outgroups and Iranian isolates obtained in this study shown in color. Bar represents 10 changes 


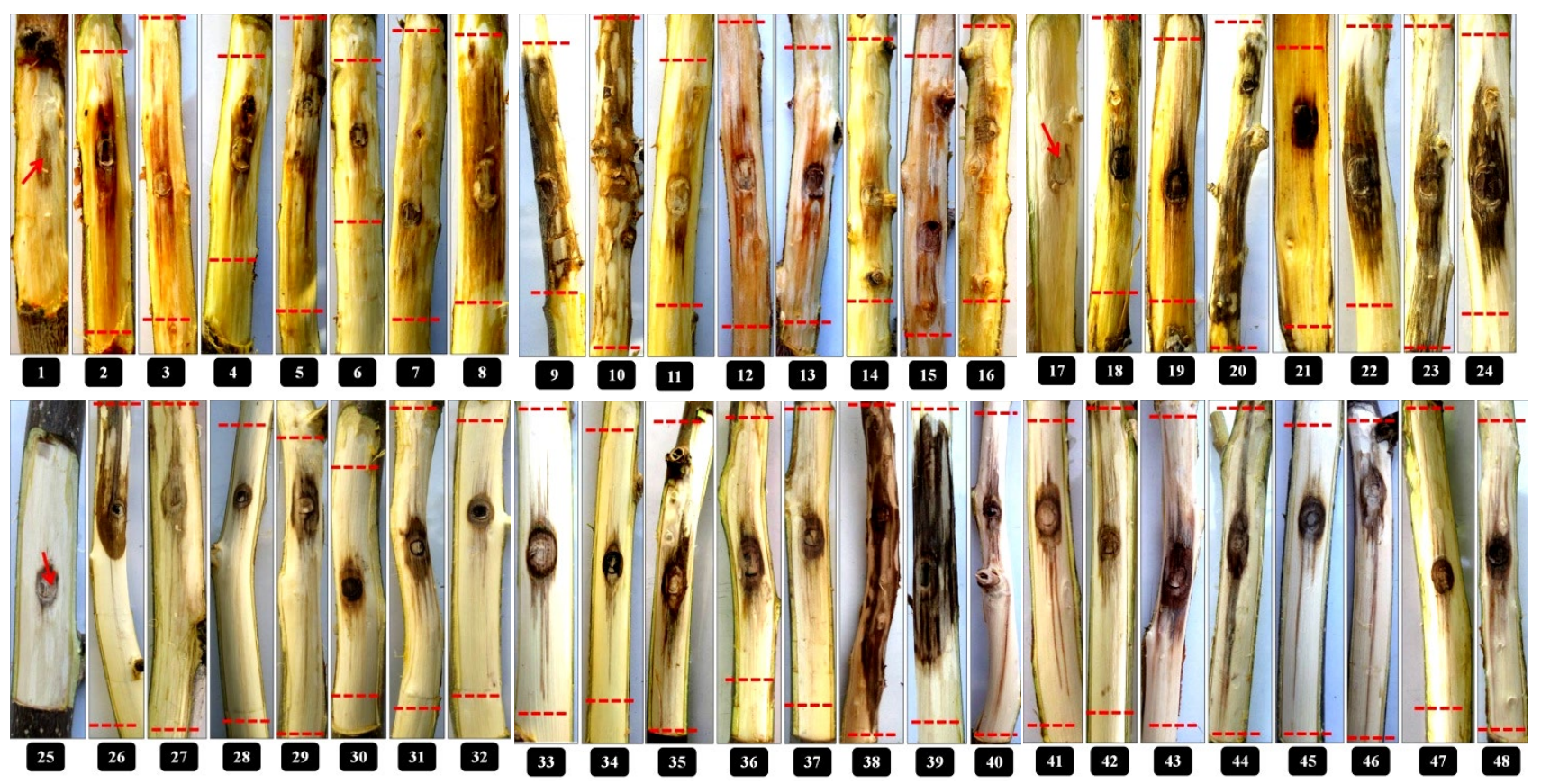

Fig. 6 Lesions obtained on pathogenicity tests of fungal species inoculated onto detached shoots of nut crops (almond, pistachio and walnut) 40 days after inoculation: (1-16) almond, 1) control (the arrow shows the point of inoculation) compared to wood discoloration caused by 2) Botryosphaeria dothidea, 3) Collophorina hispanica (IRNM112), 4) Diatrype whitmanensis, 5) Diplodia gallae, 6) Diplodia mutila, 7) Diplodia seriata (IRNBS15), 8) Eutypella sp. group1, 9) Lasiodiplodia theobromae, 10) Neofusicoccum parvum, 11) Phaeoacremonium angustius, 12) Phaeoacremonium italicum, 13) Phaeoacremonium minimum, 14) Phaeoacremonium parasiticum, 15) Phaeoacremonium viticola, 16) Pleurostoma richardsiae (IRNKPH222), (17-24) pistachio, 17) control, 18) Botryosphaeria dothidea (IRNBS61), 19) Diplodia seriata, 20) Eutypella sp. group 2, 21) Eutypella citricola, 22) Phaeoacremonium minimum, 23) Phaeoacremonium parasiticum, 24) Phaeoacremonium viticola, (25-48) walnut, 25)control, 26) Botryosphaeria dothidea (IRNBS19), 27) Cryptosphaeria pullmanensis, 28) Diplodia gallae, 29) Diplodia seriata (IRNBS23), 30) Dothiorella plurivora (IRNBS55), 31) Dothiorella sarmentorum, 32) Dothiorella viticola, 33) Eutypella sp. group1, 34) Eutypella sp. group 2, 35) Eutypella vitis, 36) Lasiodiplodia citricola, 37) Lasiodiplodia mahajangana, 38) Lasiodiplodia theobromae, 39) Neofusicoccum parvum, 40) Phaeoacremonium cinereum (IRNPm10), 41) Phaeoacremonium fraxinopennsylvanicum, 42) Phaeoacremonium italicum (IRNKPH176), 43) Phaeoacremonium minimum, 44) Phaeoacremonium parasiticum, 45) Phaeoacremonium scolyti, 46) Phaeoacremonium tuscanum, 47) Phaeoacremonium viticola, 48) Pleurostoma richardsiae (IRNPm42). 
Table 1 Mean lesion length and re-isolation frequencies of fungal species inoculated onto almond tree shoots in the pathogenicity test.

\begin{tabular}{|c|c|c|c|c|c|}
\hline \multicolumn{2}{|l|}{ Isolates } & \multicolumn{3}{|c|}{ Mean lesion length (mm) } & \multirow{2}{*}{$\begin{array}{l}\text { Re-isolation } \\
\text { frequency }(\%)\end{array}$} \\
\hline Species & Code (IRN) & Up & Down & Total & \\
\hline Botryosphaeria dothidea & BS4* & 49.60 BCDEF & $63.00 \mathrm{~B}$ & $112.60 \mathrm{BCD}$ & 71.0 \\
\hline Collophorina hispanica & $\begin{array}{l}\text { M112 } \\
\text { MSX4 }\end{array}$ & $\begin{array}{l}34.60 \text { DEFG } \\
62.40 \mathrm{ABC}\end{array}$ & $\begin{array}{l}29.00 \mathrm{CDE} \\
35.60 \mathrm{BCD}\end{array}$ & $\begin{array}{l}64.00 \text { DEF } \\
98.00 \text { BCDE }\end{array}$ & $\begin{array}{l}57.0 \\
64.0\end{array}$ \\
\hline Diatrype whitmanensis & EU1 & $17.60 \mathbf{G H}$ & $15.80 \mathrm{DE}$ & $33.40 \mathbf{F G}$ & 57.0 \\
\hline Diplodia gallae & BS8* & $78.80 \mathrm{~A}$ & $126.20 \mathrm{~A}$ & $205.00 \mathrm{~A}$ & 57.0 \\
\hline Diplodia mutila & KB5 & 36.60 CDEFG & $63.80 \mathrm{~B}$ & $100.40 \mathrm{BCDE}$ & 57.0 \\
\hline Eutypella sp. 1 & $\begin{array}{l}\mathrm{BS} 15 \\
\mathrm{BS} 35^{*} \\
\mathrm{M} 32-2\end{array}$ & $\begin{array}{l}\text { 52.40 ABCDEF } \\
\text { 36.00 CDEFG } \\
\text { 35.20 DEFG }\end{array}$ & $\begin{array}{l}50.40 \mathbf{B C} \\
43.40 \mathbf{B C D} \\
16.80 \mathbf{D E}\end{array}$ & $\begin{array}{l}102.80 \text { BCD } \\
79.40 \text { BCDEF } \\
52.00 \text { EFG }\end{array}$ & $\begin{array}{l}43.0 \\
57.0 \\
64.0\end{array}$ \\
\hline Lasiodiplodia theobromae & BS54 & $62.40 \mathrm{ABC}$ & $116.80 \mathrm{~A}$ & $179.20 \mathrm{~A}$ & 71.0 \\
\hline Neofusicoccum parvum & $\mathrm{BS} 30 *$ & $67.20 \mathbf{A B}$ & $102.80 \mathbf{A}$ & $170.00 \mathrm{~A}$ & 71.0 \\
\hline $\begin{array}{l}\text { Phaeoacremonium angustius } \\
\text { Phaeoacremonium italicum }\end{array}$ & $\begin{array}{l}\text { KPH477-1 } \\
\text { Pm39 }\end{array}$ & $\begin{array}{l}32.60 \text { EFG } \\
28.40 \text { FGH }\end{array}$ & $\begin{array}{l}31.80 \text { BCDE } \\
42.00 \mathbf{B C D}\end{array}$ & $\begin{array}{l}64.40 \text { CDEF } \\
70.40 \text { BCDEF }\end{array}$ & $\begin{array}{l}71.0 \\
64.0\end{array}$ \\
\hline $\begin{array}{l}\text { Phaeoacremonium minimum } \\
\text { Phaeoacremonium parasiticum } \\
\text { Phaeoacremonium viticola }\end{array}$ & $\begin{array}{l}\text { KPH178 } \\
\text { Pm33 } \\
\text { KPH17S }\end{array}$ & $\begin{array}{l}40.20 \text { BCDEFG } \\
61.00 \text { ABCD } \\
41.00 \text { BCDEFG }\end{array}$ & $\begin{array}{l}31.40 \text { BCDE } \\
55.00 \text { BC } \\
39.20 \text { BCD }\end{array}$ & $\begin{array}{l}71.60 \text { BCDEF } \\
116.00 \text { B } \\
80.20 \text { BCDEF }\end{array}$ & $\begin{array}{l}86.0 \\
64.0 \\
71.0\end{array}$ \\
\hline Pleurostoma richardsiae & $\begin{array}{l}\text { KPH222 } \\
\text { Pm24 }\end{array}$ & $\begin{array}{l}45.80 \text { BCDEF } \\
55.80 \text { ABCDE }\end{array}$ & $\begin{array}{l}63.00 \mathrm{~B} \\
57.20 \mathrm{BC}\end{array}$ & $\begin{array}{l}108.80 \mathbf{B C D} \\
113.00 \mathbf{B C}\end{array}$ & $\begin{array}{l}57.0 \\
64.0\end{array}$ \\
\hline $\begin{array}{l}\text { Control } \\
\text { LSD }(P<0.05)\end{array}$ & $\begin{array}{l}- \\
-\end{array}$ & $\begin{array}{l}1.80 \mathbf{H} \\
27.104\end{array}$ & $\begin{array}{l}2.40 \mathbf{E} \\
32.991\end{array}$ & $\begin{array}{l}4.20 \mathbf{G} \\
48.857\end{array}$ & 0 \\
\hline
\end{tabular}

Different letters in bold face indicate significant differences only within a column at $P=0.05$.

* Isolates obtained from wood debris. 
Table 2 Mean lesion length and re-isolation frequencies of fungal species inoculated onto pistachio tree shoots in the pathogenicity test

\begin{tabular}{|c|c|c|c|c|c|}
\hline \multicolumn{2}{|l|}{ Isolates } & \multicolumn{3}{|c|}{ Mean lesion length (mm) } & \multirow{2}{*}{$\begin{array}{l}\text { Re-isolation } \\
\text { frequency }(\%)\end{array}$} \\
\hline Species & Code (IRN) & Up & Down & Total & \\
\hline Botryosphaeria dothidea & $\begin{array}{l}\text { BS48 } \\
\text { BS61* }\end{array}$ & $\begin{array}{l}37.600 \mathbf{A B} \\
41.800 \mathbf{A B}\end{array}$ & $\begin{array}{l}25.200 \mathrm{BC} \\
54.200 \mathrm{~A}\end{array}$ & $\begin{array}{l}62.80 \mathrm{BCD} \\
96.00 \mathrm{~A}\end{array}$ & $\begin{array}{l}57.0 \\
50.0\end{array}$ \\
\hline Diplodia seriata & $\mathrm{BS} 71^{*}$ & $31.800 \mathbf{A B}$ & $28.800 \mathrm{BC}$ & $60.60 \mathrm{BCD}$ & 43.0 \\
\hline Eutypella sp. 2 & M1 & $45.800 \mathbf{A}$ & $62.600 \mathrm{~A}$ & $108.40 \mathrm{~A}$ & 78.0 \\
\hline Eutypella citricola & M4 & $14.800 \mathrm{D}$ & $19.600 \mathrm{C}$ & $34.40 \mathrm{D}$ & 43.0 \\
\hline Phaeoacremonium minimum & $\operatorname{Pm} 37$ & $32.200 \mathbf{A B}$ & $32.000 \mathrm{BC}$ & $64.20 \mathrm{BC}$ & 64.0 \\
\hline $\begin{array}{l}\text { Phaeoacremonium } \\
\text { parasiticum }\end{array}$ & $\operatorname{Pm} 30$ & $16.000 \mathrm{CD}$ & $21.600 \mathrm{BC}$ & $37.60 \mathrm{CD}$ & 71.0 \\
\hline Phaeoacremonium viticola & $\operatorname{Pm} 26$ & $29.800 \mathrm{BC}$ & $36.600 \mathrm{~B}$ & $66.40 \mathrm{~B}$ & 50.0 \\
\hline Control & - & $2.000 \mathrm{D}$ & $1.600 \mathrm{D}$ & $3.60 \mathbf{E}$ & 0 \\
\hline LSD $(P<0.05)$ & - & 14.891 & 16.615 & 28.511 & \\
\hline
\end{tabular}

Different letters in bold face indicate significant differences only within a column at $P=0.05$.

* Isolates obtained from wood debris. 
Table 3 Mean lesion length and re-isolation frequencies of fungal species inoculated onto walnut tree shoots in the pathogenicity test.

\begin{tabular}{|c|c|c|c|c|c|}
\hline \multicolumn{2}{|l|}{ Isolates } & \multicolumn{3}{|c|}{ Mean lesion length (mm) } & \multirow{2}{*}{$\begin{array}{l}\text { Re-isolation } \\
\text { frequency }(\%)\end{array}$} \\
\hline Species & Code (IRN) & Up & Down & Total & \\
\hline \multirow[t]{2}{*}{ Botryosphaeria dothidea } & KB213 & $16.20 \mathrm{NOP}$ & 32.80 IJKLM & $49.00 \mathrm{MN}$ & 75.0 \\
\hline & BS19* & $87.20 \mathrm{ABC}$ & $115.80 \mathrm{BC}$ & $203.00 \mathbf{A B C}$ & 78.0 \\
\hline $\begin{array}{l}\text { Cryptosphaeria } \\
\text { pullmanensis }\end{array}$ & SCYT3 & $75.80 \mathrm{ABCDE}$ & 85.60 CDEF & 162.40 CDEF & 66.6 \\
\hline Diplodia gallae & BS6 & $95.60 \mathrm{~A}$ & $127.00 \mathbf{A B}$ & $222.60 \mathbf{A B}$ & 78.0 \\
\hline \multirow[t]{2}{*}{ Diplodia seriata } & KB211 & 23.80 MNOP & 29.80 JKLM & $53.60 \mathrm{MN}$ & 58.0 \\
\hline & $\mathrm{BS} 23 *$ & 64.20 DEFG & 90.40 CDEF & 154.60 CDEFG & 64.0 \\
\hline \multirow[t]{2}{*}{ Dothiorella plurivora } & KB220 & 20.20 MNOP & $25.80 \mathbf{L M}$ & $46.00 \mathrm{MN}$ & 78.3 \\
\hline & BS55* & 56.60 EFGHIJ & 59.20 FGHIJK & 115.80 FGHIJK & 64.0 \\
\hline Dothiorella sarmentorum & BS18* & 58.40 DEFGHI & 78.40 DEFGH & 136.80 EFGH & 57.0 \\
\hline Dothiorella viticola & BS28 & 30.60 LMNO & 34.40 IJKLM & $64.60 \mathbf{L M}$ & 50.0 \\
\hline Eutypella sp. 1 & M32-1 & 39.40 HIJKLM & 35.00 IJKLM & 74.40 JKLM & 50.0 \\
\hline Eutypella sp. 2 & $\mathrm{M} 8 *$ & $89.20 \mathbf{A B}$ & $106.00 \mathrm{BCD}$ & $195.20 \mathbf{A B C D}$ & 50.0 \\
\hline Eutypella vitis & SU1 & 72.60 BCDEF & 75.00 DEFGH & 147.60 DEFG & 55.0 \\
\hline Lasiodiplodia citricola & KB3 & 36.00 JKLMN & 31.60 IJKLM & $67.60 \mathbf{K L M}$ & 75.0 \\
\hline Lasiodiplodia mahajangana & KB208 & 58.00 EFGHIJ & 51.80 GHIJKL & 109.80 GHIJKL & 71.3 \\
\hline Lasiodiplodia theobromae & KB245 & $88.00 \mathbf{A B C}$ & $156.40 \mathrm{~A}$ & $244.40 \mathrm{~A}$ & 93.0 \\
\hline Neofusicoccum parvum & BS5 & 80.40 ABCD & $95.00 \mathrm{BCDE}$ & 175.40 BCDE & 86.0 \\
\hline Phaeoacremonium & $\mathrm{K} 72 \mathrm{~S}$ & 66.20 CDEF & 84.40 CDEFG & 150.60 DEFG & 50.0 \\
\hline cinereum & КРH177 & $13.20 \mathrm{OP}$ & 29.40 JKLM & $42.60 \mathrm{MN}$ & 58.3 \\
\hline & Pm10 & 59.60 DEFGH & 75.60 DEFGH & 135.20 EFGHI & 57.0 \\
\hline $\begin{array}{l}\text { Phaeoacremonium } \\
\text { fraxinopennsylvanicum }\end{array}$ & K137S & 37.80 HIJKLMN & 47.20 HIJKL & 85.00 IJKLM & 57.0 \\
\hline
\end{tabular}


Table 3 Continued.

\begin{tabular}{|c|c|c|c|c|c|}
\hline \multicolumn{2}{|l|}{ Isolates } & \multicolumn{3}{|c|}{ Mean lesion length (mm) } & \multirow{2}{*}{$\begin{array}{l}\text { Re-isolation } \\
\text { frequency }(\%)\end{array}$} \\
\hline Species & Code (IRN) & $\mathbf{U P}$ & Down & Total & \\
\hline Phaeoacremonium italicum & $\begin{array}{l}\text { КРH176 } \\
\text { КРH209 }\end{array}$ & $\begin{array}{l}33.40 \mathrm{KLMNO} \\
13.60 \mathrm{OP}\end{array}$ & $\begin{array}{l}26.60 \text { KLM } \\
30.00 \mathrm{JKLM}\end{array}$ & $\begin{array}{l}60.00 \mathrm{LMN} \\
43.60 \mathrm{MN}\end{array}$ & $\begin{array}{l}58.3 \\
75.0\end{array}$ \\
\hline Phaeoacremonium minimum & KPH426S & 63.60 DEFG & 61.00 FGHIJ & 124.60 EFGHIJ & 64.0 \\
\hline Phaeoacremonium parasiticum & $\operatorname{Pm} 27$ & 58.80 DEFGHI & 64.60 EFGHI & 123.40 FGHIJ & 71.0 \\
\hline Phaeoacremonium scolyti & $\mathrm{KPH} 2 \mathrm{~S}$ & 42.20 GHIJKLM & 49.80 HIJKL & 92.00 HIJKLM & 78.0 \\
\hline Phaeoacremonium tuscanum & G14S & 53.20 FGHIJK & 70.60 EFGH & 123.80 FGHIJ & 86.0 \\
\hline Phaeoacremonium viticola & KPH16S & 37.40 IJKLMN & 34.00 IJKLM & $71.40 \mathbf{~ K L M}$ & 58.3 \\
\hline Pleurostoma richardsiae & $\begin{array}{l}\text { KPH423 } \\
\text { Pm42 }\end{array}$ & $\begin{array}{l}41.20 \text { HIJKLM } \\
51.40 \text { FGHIJKL }\end{array}$ & $\begin{array}{l}21.40 \text { LM } \\
79.20 \text { DEFGH }\end{array}$ & $\begin{array}{l}62.60 \text { LM } \\
130.60 \text { EFGHI }\end{array}$ & $\begin{array}{l}66.6 \\
64.0\end{array}$ \\
\hline Control & - & $5.20 \mathbf{P}$ & $6.20 \mathrm{M}$ & $11.40 \mathbf{~ N}$ & 0 \\
\hline LSD $(P<0.05)$ & - & 22.033 & 33.386 & 50.916 & \\
\hline
\end{tabular}

* Isolates obtained from wood debris. 